\title{
Metrology Measurement Capabilities
}

Federal Manufacturing \& Technologies

Leon M. Barnes

KCP-613-6734

Published November 2003

Final Report

Approved for public release; distribution is unlimited.

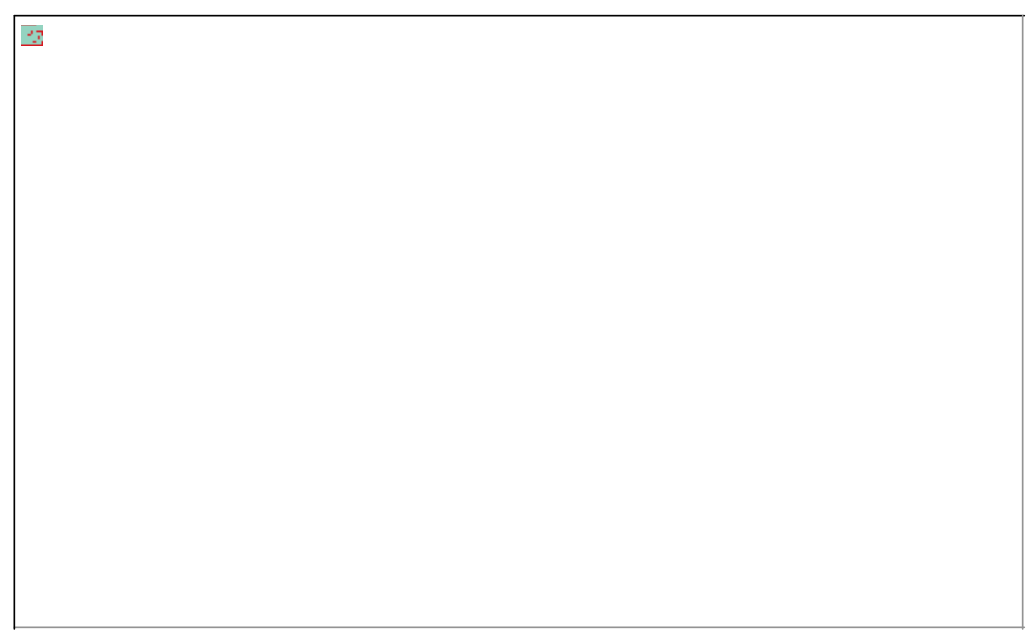

Prepared under prime contract DE-ACO4-01AL66850 for the United States Department of Energy 


\section{DISCLAIMER}

This report was prepared as an account of work sponsored by an agency of the United States Government. Neither the United States Government nor any agency thereof, nor any of their employees, nor any of their contractors, subcontractors or their employees, makes any warranty, express or implied, or assumes any legal liability or responsibility for the accuracy, completeness, or any third party's use or the results of such use of any information, apparatus, product, or process disclosed, or represents that its use would not infringe privately owned rights. Reference herein to any specific commercial product, process, or service by trade names, trademark, manufacturer, or otherwise, does not necessarily constitute or imply its endorsement, recommendation, or favoring by the United States Government or any agency thereof or its contractors or subcontractors. The views and opinions of authors expressed herein do not necessarily state or reflect those of the United States Government or any agency thereof.

All data prepared, analyzed and presented has been developed in a specific context of work and was prepared for internal evaluation and use pursuant to that work authorized under the referenced contract. Reference herein to any specific commercial product, process or service by trade name, trademark, manufacturer, or otherwise, does not necessarily constitute or imply its endorsement, recommendation, or favoring by the United States Government, any agency thereof or Honeywell Federal Manufacturing \& Technologies, LLC.

Printed in the United States of America.

This report has been reproduced from the best available copy.

Available to DOE and DOE contractors from the Office of Scientific and Technical Information,

P. O. Box 62, Oak Ridge, Tennessee 37831; prices available from (865) 576-8401, FTS 626-8401 Facsimile: (865) 576-5728, E-mail: reports@adonis.osti.gov

Available to the public from the National Technical Information Service, U. S. Department of Commerce, 5285 Port Royal Rd., Springfield, Virginia 22161, (800) 553-6847, Facsimile:

(703) 605-6900, E-mail: orders@ntis.fedworld.gov

A prime contractor with the United States Department of Energy under prime contract DE-ACO4-01AL66850.
Honeywell

Federal Manufacturing

\& Technologies

P. O. Box 419159

Kansas City, Missouri 
64141-6159 
KCP-613-6734

Distribution Category UC-706

Approved for public release; distribution is unlimited.

\section{METROLOGY MEASUREMENT CAPABILITIES}

Leon M. Barnes

Published November 2003 


\title{
Table of Contents
}

\author{
INTRODUCTION \\ MECHANICAL \\ DIMENSIONAL \\ Length and Coordinate Measurement \\ Gage Block Measurement \\ Roundness Measurement \\ Flatness Measurement \\ Angle Measurement \\ Surface Finish Measurement \\ MASS, FORCE, AND TORQUE AND VOLUMETRIC \\ Mass Measurement \\ Force Measurement \\ Torque Measurement \\ Laboratory Glassware Volume \\ Vibration \\ Mechanical Shock \\ Sound Level \\ ENVIRONMENTAL, GAS, LIQUID \\ TEMPERATURE, HUMIDITY \\ Temperature \\ Humidity \\ GAS, LIQUID \\ Pressure \\ Vacuum \\ Air Velocity \\ Gas Leaks \\ Gas Flow \\ Viscosity \\ ELECTRICAL \\ ELECTRICAL \\ DC Electrical Measurement \\ DC Voltage \\ DC Current \\ DC Resistance \\ AC Electrical Measurement \\ AC Voltage
}


AC Current

AC Ratio

Capacitance and Inductance

Frequency and Time

RF/Microwave Measurements

Air Lines

Attenuators and Terminations

Network Analyzers and Attenuation Systems

Noise Source

Thermistor Mounts

Probe Station

Power System

OPTICAL AND RADIATION

OPTICAL AND RADIATION

Optical Radiometric Measurement

Optical Photometric Measurement

Radiation Measurement 


\section{Measurement Capability Tables}

Dimensional Measurement Capability

Angle, Roughness, and Flatness Measurement Capability

Mass, Force, and Torque Measurement Capability

Laboratory Glassware Volumetric Measurement Capability

Vibration, Acceleration, Shock, Sound Level Measurement Capability

Temperature, Humidity Measurement Capability

Gas, Liquid Measurement Capability

Electrical DC Measurement Capability

AC Measurement Capability

Electrical Radio Frequency/Microwave Measurement Capability

Optical Radiometric Measurement Capability

Optical Photometric Measurement Capability

\section{Measurement Standards Tables}

PAG

Dimensional Standards

Angle, Roughness, and Flatness Standards

Mass, Force, and Torque Standards

Vibration, Acceleration, and Shock Standards

Temperature, Humidity Standards

Pressure Standards

Air Velocity Standards

Gas Leak, Flow Rate, Viscosity Standards

DC Current and Voltage Standards

DC Resistance and Ratio Standards

AC Current, Voltage, and Ratio Standards

Inductance, Capacitance, and AC Resistance Standards

Frequency and Time Standards

Radio Frequency and Microwave Standards

Optical Radiometric Measurement Standards

Optical Photometric Measurement Standards 


\section{Honeywell Federal Manufacturing \& Technologies Metrology Calibration Capabilities INTRODUCTION}

This document contains descriptions of Federal Manufacturing \& Technologies (FM\&T) Metrology capabilities, traceability flow charts, and the measurement uncertainty of each measurement capability.

Metrology provides NIST traceable precision measurements or equipment calibration for a wide variety of parameters, ranges, and state-of-the-art uncertainties. Metrology laboratories conform to the requirements of the Department of Energy Development and Production Manual Chapter 8.4, ANSI/ISO/IEC ANSI/ISO/IEC 17025:2000, and ANSI/NCSL Z540-1 (equivalent to ISO Guide 25).

FM\&T Metrology laboratories are accredited by NVLAP for the parameters, ranges, and uncertainties listed in the specific scope of accreditation under NVLAP Lab code 200108-0. See the Internet at http://ts.nist.gov/ts/htdocs/210/214/scopes/2001080.pdf. These parameters are summarized in the table at the bottom of this introduction.

The Honeywell Federal Manufacturing \& Technologies (FM\&T) Metrology Department has developed measurement technology and calibration capability in four major fields of measurement:

Mechanical;

Environmental, Gas, Liquid;

Electrical (DC, AC, RF/Microwave); and

Optical and Radiation.

Metrology Engineering provides the expertise to develop measurement capabilities for virtually any type of measurement in the fields listed above.

A strong audit function has been developed to provide a means to evaluate the calibration programs of our suppliers and internal calibration organizations. Evaluation includes measurement audits and technical surveys. 


\section{Measurement and Calibration Capabilities}

\section{*NVLAP Accredited in these parameters}

\author{
Dimensional \\ Length * \\ Coordinate Measuring Machines * \\ Coordinate Measurement * \\ Angle Measurement * \\ Gage Blocks * \\ Glass Scales * \\ Internal/External Diameters * \\ Roundness * \\ Spherical Diameter * \\ Flatness Measurement * \\ Thread Wires * \\ Surface Finish Measurement
}
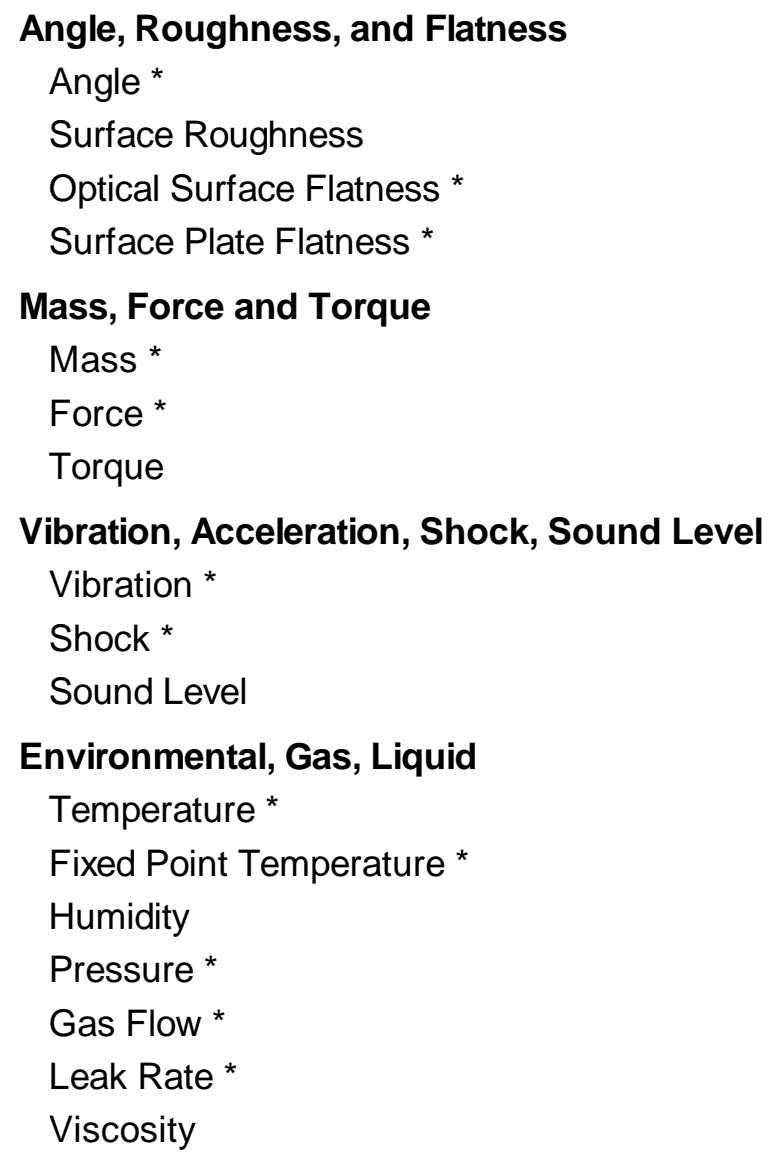

\author{
Electrical AC/DC \\ AC/DC Voltage * \\ AC/DC Current \\ AC/DC Resistance * \\ Capacitance, Inductance * \\ Frequency, Time of Day * \\ DC Magnetic Field Density

\section{Electrical RF/Microwave} \\ Attenuation * \\ RF Power * \\ RF Reflection Coefficient * \\ Network Analyzers \\ Laboratory Glassware Volume \\ Burets \\ Volumetric Pipets \\ Measuring Pipets \\ Volumetric Flasks \\ Graduated Cylinders
}

Optical Radiometric, Photometric

Optical Transmittance

Optical Spectral Response

Laser Average Power

Laser Peak Power

LED Power

Ultraviolet Irradiance

Illuminance

Monochrometers

X-Ray Film Density

Luminous Intensity

HeNe Laser Frequency, Wavelength * 


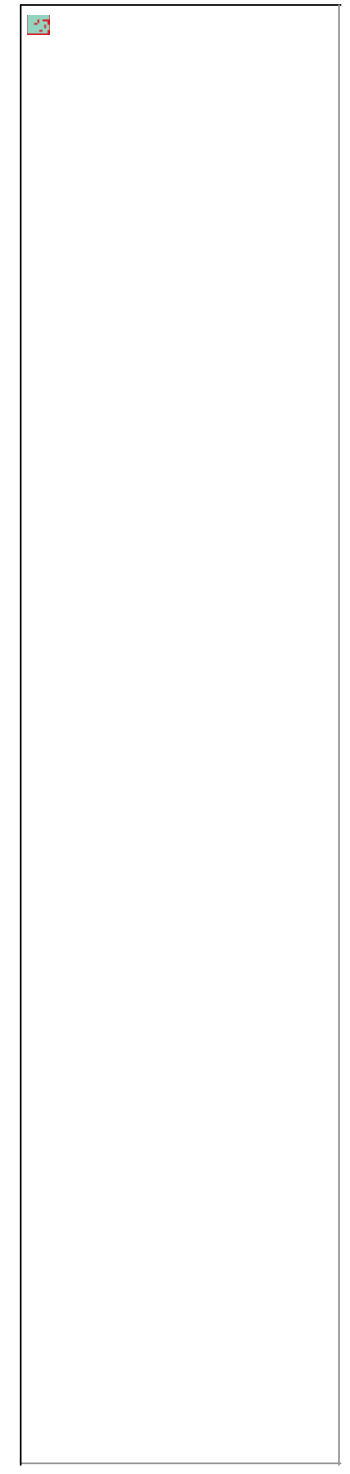

\section{DIMENSIONAL}

\section{Length and Coordinate Measurement}

Three-dimensional coordinate standards are measured interferometrically using a helium-neon laser light source. Laser interferometers are mounted on each axis of a three-dimensional coordinate measuring machine. Corrections are made for wavelength variation due to air density by an on-line computer. Uncertainties are listed in the accompanying table. Many length-measuring systems are calibrated using the laser interferometer.

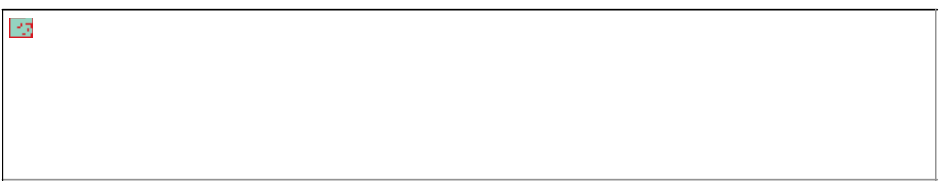




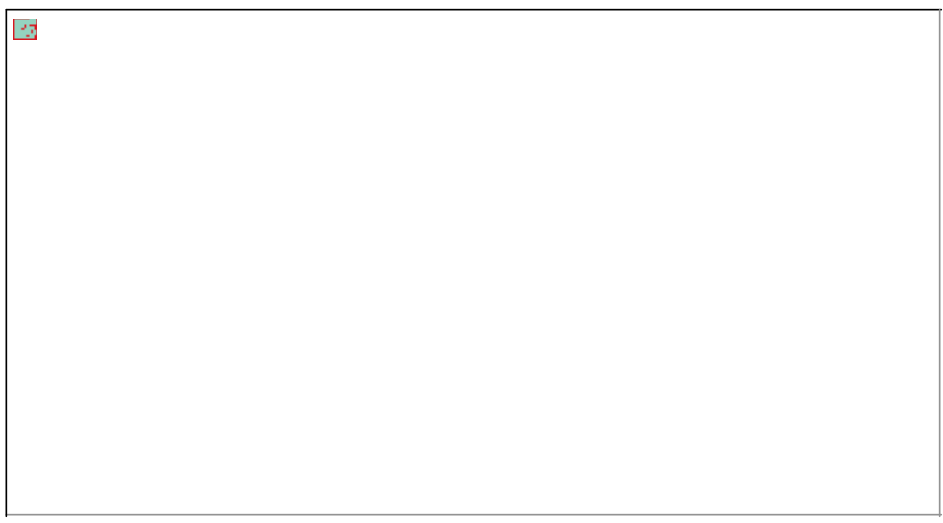

\section{Shelton CMM With CMM Calibration Artifact}

\section{Gage Block Measurement}

Gage blocks are compared to blocks certified by the Primary Standards Laboratory (PSL) using a gage block comparator.

\section{Roundness Measurement}

Roundness measurements are made using a roundness machine with an air-bearing spindle. Spindle error and high accuracy roundness measurements are made using a reversal technique that separates spindle error from roundness error.

\section{Flatness Measurement}

Flatness of small surfaces is measured directly using an optical flat or an optical interferometer. Reference optical flats are calibrated using the three-flat method and a polychromatic fringe viewer.

Surface plate flatness is measured using an autocollimator and two mirrors. The flatness of the surface plate is determined using both the Moody method and a three-dimensional least squares technique.

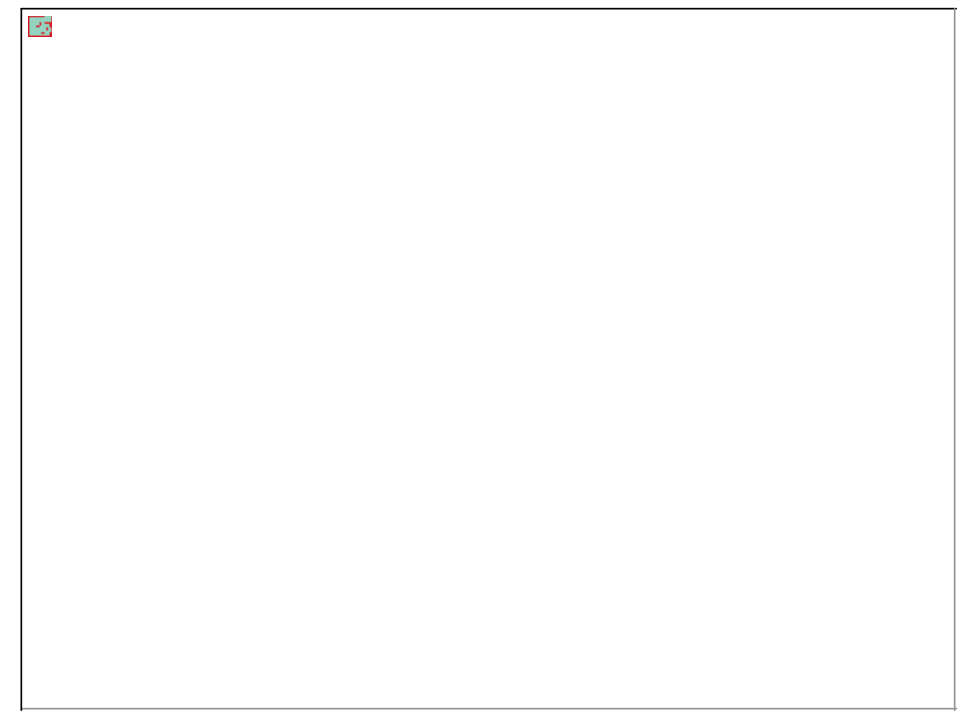

\section{Angle Measurement}

Small angles are measured using an autocollimator. The autocollimator is calibrated using a small-angle generator consisting of a pivot arm of known length and a set of certified gage 
blocks.

Large angles are measured using an autocollimator, a rotary table, an optical polygon, and angle gage blocks.

\section{Surface Finish Measurement}

Surface finish standards are measured using a profile-type surface finish analyzer. The surface finish analyzer is calibrated using a lever arm calibrator and roughness standards calibrated by NIST.

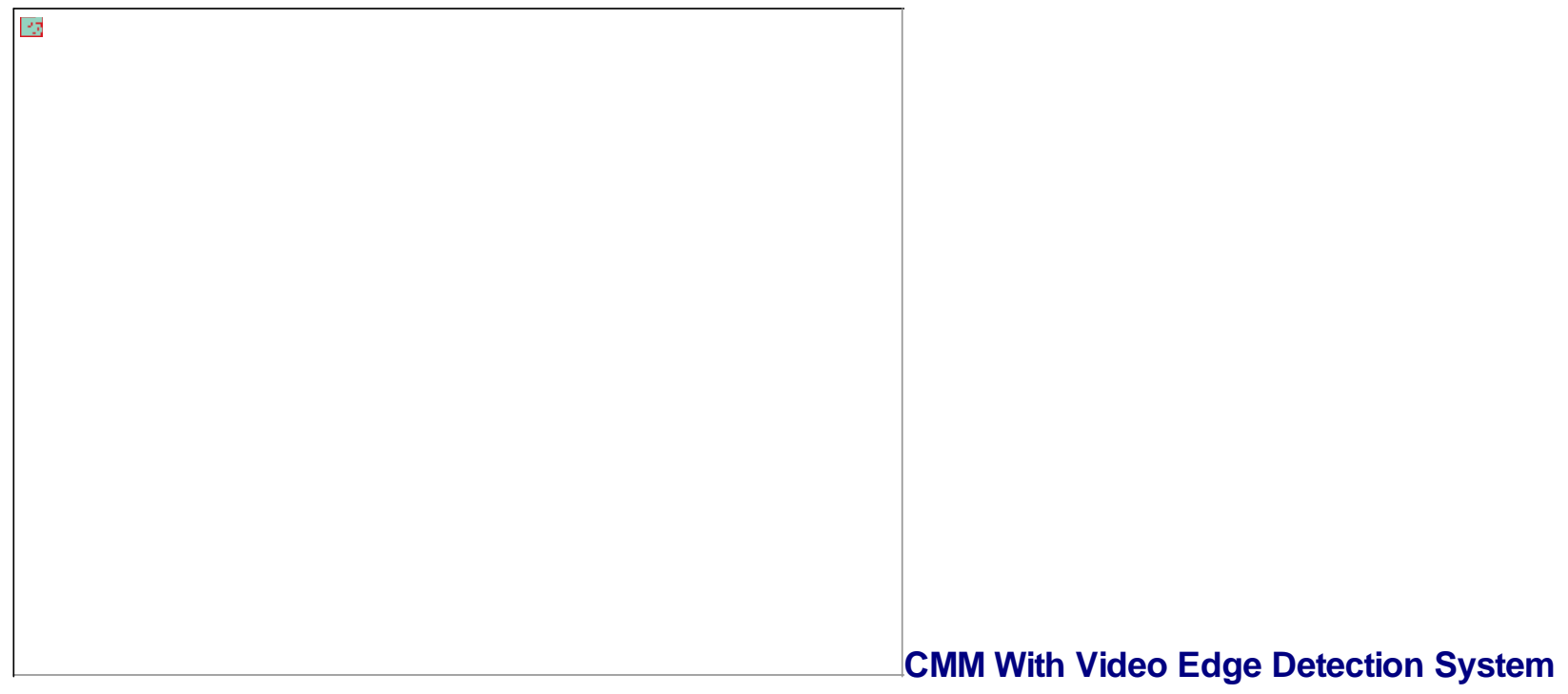




\section{Dimensional Measurement Capability}

\begin{tabular}{|c|c|c|}
\hline Type & Range & Measuring Uncertainty (?) $k=2$ \\
\hline \multirow[t]{2}{*}{ Gage Blocks } & To 4 in. & $2.5 \mathrm{~min} .+0.44 \mathrm{ppm}$ \\
\hline & $>4$ to $20 \mathrm{in}$. & $5.4 \min .+0.49$ ppm \\
\hline \multirow[t]{3}{*}{ Coordinate Measurement * } & Axial & $10 \mathrm{~min}+0.5 \mathrm{ppm}$ \\
\hline & Planar ** & 75 min. + 1 ppm \\
\hline & Spatial *** & 75 min. + 12 ppm \\
\hline 1-D Ball Plates & To 48 in. & $20 \mathrm{~min}+1.0 \mathrm{ppm}$ \\
\hline 2-D Ball Plates & 36 in. by 36 in. & $20 \mathrm{~min}+1.0 \mathrm{ppm}$ \\
\hline Step Gages & To 24 in. & $20 \mathrm{~min}+1.0$ ppm. \\
\hline Internal Diameters & $\begin{array}{l}0.04 \text { to } 1 \mathrm{in.} \\
1 \text { to } 2 \text { in. } \\
2 \text { to } 14 \text { in. }\end{array}$ & $\begin{array}{l}9 \text { min. } \\
10 \text { min. } \\
\text { Determined by Test. }\end{array}$ \\
\hline Single Axis Glass Line Scales & $\begin{array}{l}0 \text { to } 2 \text { in. } \\
>2 \text { to } 12 \text { in. }\end{array}$ & $\begin{array}{l}18 \mathrm{~min} . \\
32 \mathrm{~min} .\end{array}$ \\
\hline Spherical Diameter & $\begin{array}{l}0 \text { to } 1 \mathrm{in} . \\
1 \text { to } 2 \mathrm{in} .\end{array}$ & $\begin{array}{l}12 \mathrm{~min} . \\
13 \mathrm{~min} .\end{array}$ \\
\hline Cylindrical Plug Gages & 0 to $1 \mathrm{in.}$ & $7.3 \mathrm{~min}$. \\
\hline Squares & To 24 in. by 36 in. & $30 \mathrm{~min}$. \\
\hline Straight Edges & To 48 in. & $5 \mathrm{~min}$. \\
\hline Roundness & To 18-in. diameter & $3 \mathrm{~min}$. \\
\hline Thread Wires & All standard pitches & $8 \mathrm{~min}$. \\
\hline
\end{tabular}

* Maximum range of length-coordinate measurement is $x=48$ in., $y=36$ in., and $z=12$ in.

** Certain artifacts, such as ball plates, can be designed in such a way to allow the use of a single-axis calibration technique. The technique requires the balls to be located in an orderly array with one ball located in the center. Artifacts of this design can be certified to $\pm(20 \mathrm{~min}+1.0 \mathrm{ppm})$.

*** 18 in. by 12 in. by 12 in. volume. 


\section{Dimensional Calibration Traceability}

\section{Dimensional Standards}

\begin{tabular}{|c|c|c|c|c|}
\hline Code & Description & Manufacturer & Range & Uncertainty (?) (k=2) \\
\hline D1 & $\begin{array}{l}\text { Standard Gage } \\
\text { Blocks }\end{array}$ & $\begin{array}{l}\text { Do All } \\
\text { Pratt \& Whitney }\end{array}$ & $\begin{array}{l}\text { To } 4 \text { in. } \\
5 \text { to } 20 \text { in. }\end{array}$ & $\begin{array}{l}1.6 \mathrm{~min} .+0.6 \mathrm{ppm} \\
6 \mathrm{~min} .+0.5 \mathrm{ppm}\end{array}$ \\
\hline D2 & $\begin{array}{l}\text { Gage Block } \\
\text { Comparators }\end{array}$ & $\begin{array}{l}\text { Link } \\
\text { Federal } \\
\text { Pratt \& Whitney }\end{array}$ & $\begin{array}{l}0 \text { to } 2 \text { in. } \\
0 \text { to } 4 \text { in. } \\
0 \text { to } 20 \text { in. }\end{array}$ & $\begin{array}{l}3 \mathrm{~min} . \\
3 \mathrm{~min} . \\
3 \mathrm{~min} .\end{array}$ \\
\hline D3 & $\begin{array}{l}\text { Transfer Standard } \\
\text { Gage Blocks }\end{array}$ & $\begin{array}{l}\text { Do All } \\
\text { Pratt \& Whitney }\end{array}$ & $\begin{array}{l}\text { To } 4 \text { in. } \\
5 \text { to } 20 \text { in. }\end{array}$ & $\begin{array}{l}2.5 \text { min. }+0.4 \text { ppm } \\
5.4 \text { min. }+0.5 \text { ppm }\end{array}$ \\
\hline D4 & Lever Arm Calibrator & $\begin{array}{l}\text { r FM\&T Metrology } \\
\text { Mitutoyo }\end{array}$ & $\begin{array}{l}0 \text { to } 0.0002 \text { in } \\
0 \text { to } 0.05 \text { in. }\end{array}$ & $\begin{array}{l}0.25 \text { min. }+0.5 \% \text { of travel } \\
10 \text { min. }+0.1 \% \text { of travel }\end{array}$ \\
\hline D5 & Measuring Machine & Pratt \& Whitney & 0 to $14 \mathrm{in}$. & 3 min. +2 ppm \\
\hline D6 & $\begin{array}{l}\text { Standard Gaging } \\
\text { Balls }\end{array}$ & AA Industries & $\begin{array}{l}1 / 16 \text { to } 1 \text { in. } \\
\text { (1/32-in. increments) }\end{array}$ & $6 \mathrm{~min}$. \\
\hline D7 & $\begin{array}{l}\text { Interference } \\
\text { Microscope }\end{array}$ & Zeiss & 0 to $0.01 \mathrm{in.}$ & $1 \mathrm{~min}$. \\
\hline D8 & Laser Interferometer & r Hewlett-Packard & NA & 0.05 ppm \\
\hline D9 & Measuring Machine & Pratt \& Whitney & $1 \mathrm{in.}$ & $10 \mathrm{~min}$. \\
\hline D10 & Measuring Machine & FM\&T Metrology & 0 to 2 in. & $8 \mathrm{~min}$. \\
\hline D11 & $\begin{array}{l}\text { Standard Plug } \\
\text { Gages }\end{array}$ & Lincoln & 0.050 to $1 \mathrm{in}$. & $4.6 \mathrm{~min}$. \\
\hline D12 & $\begin{array}{l}\text { Coordinate } \\
\text { Measuring Machine }\end{array}$ & $\begin{array}{l}\text { SIP/FM\&T } \\
\text { Metrology }\end{array}$ & 0 to 16 in & $\begin{array}{l}\text { Included in Line Scale } \\
\text { Process }\end{array}$ \\
\hline D13 & $\begin{array}{l}\text { Roundness } \\
\text { Measuring Machine }\end{array}$ & Bendix A \& M & 18-in. diameter & $3 \mathrm{~min}$. \\
\hline D14 * & $\begin{array}{l}\text { Coordinate } \\
\text { Measuring Machine }\end{array}$ & Shelton & $\begin{array}{l}x \text { axis } \\
y \text { axis } \\
z \text { axis } \\
x \text {-y plane }{ }^{\star *}\end{array}$ & $\begin{array}{l}10 \mathrm{~min} .+0.5 \mathrm{ppm} \\
10 \mathrm{~min} .+0.5 \mathrm{ppm} \\
30 \mathrm{~min} .+0.5 \mathrm{ppm} \\
71 \mathrm{~min} .+0.6 \mathrm{ppm}\end{array}$ \\
\hline
\end{tabular}

* Maximum range: $x=48$ in., $y=36$ in., $z=12$ in.

** Certain artifacts, such as ball plates, can be designed in such a way to allow the use of a single-axis calibration technique. This requires the balls to be located in an orderly array with one ball located in the center. Artifacts of this design can be certified to ?(20 min + $1.0 \mathrm{ppm}$.).

\section{Angle, Roughness, and Flatness Measurement Capability}




\begin{tabular}{|l|l|l|}
\hline Type & Range & Measuring Uncertainty (?) (k=2) \\
\hline Angle (Polygon/Index Table) & 0 to $360^{\circ}$ & 0.6 arc second \\
\hline Angle Blocks & To $45 ?$ & 1.1 arc second \\
\hline Autocollimators & 0 to 600 arc seconds & 0.3 arc second $+0.25 \%$ \\
\hline Surface Roughness & 0.024 in. (Peak-to-Peak) & $0.4+1.2 \%$ of Reading (in min. Ra) \\
\hline Optical Surface Flatness & To 12 -in. diameter & $\begin{array}{l}1.2 \text { min. (Three Flat Method) } \\
2 \text { min. (Interferometer) } \\
4 \text { min. (Direct Comparison) }\end{array}$ \\
\hline Surface Plate Flatness & Up to $8 \mathrm{ft}$ Diagonal & 30 min. + 2 min./ft ${ }^{2}$ \\
\hline
\end{tabular}

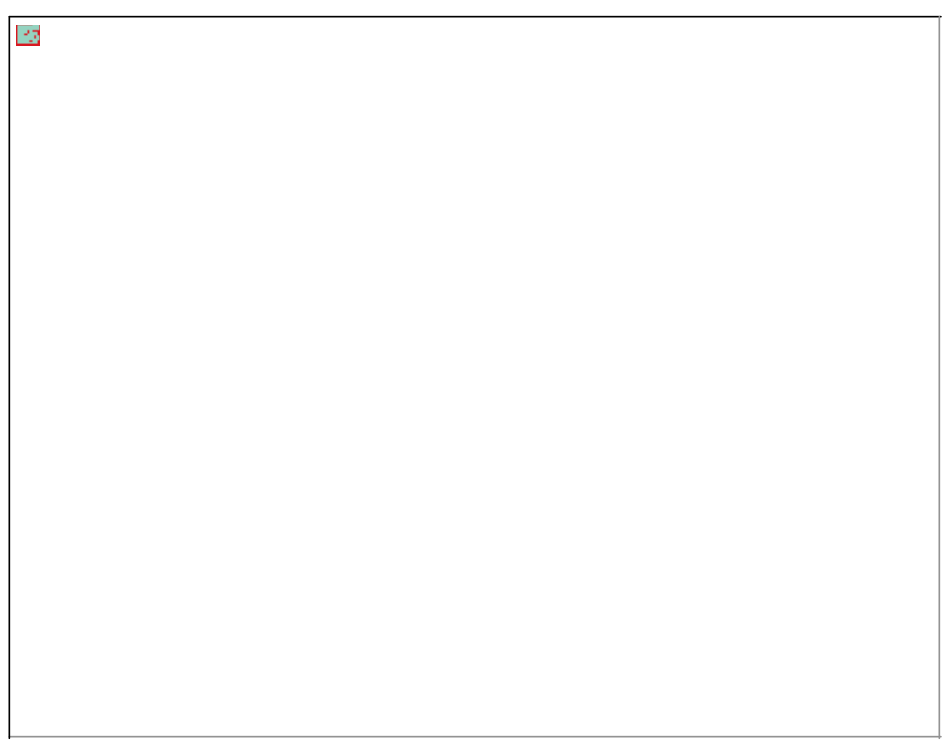

Angle, Roughness, Flatness Traceability 
Angle, Roughness, and Flatness Standards

\begin{tabular}{|c|c|c|c|c|}
\hline Code & Description & Manufacturer & Range & Uncertainty (?) (k=2) \\
\hline ARF1 & $\begin{array}{l}\text { Standard Angle } \\
\text { Gage Blocks }\end{array}$ & Webber & $\begin{array}{l}1 \text { arc second to } 45 ? \\
\text { (16 blocks) }\end{array}$ & 0.7 arc second \\
\hline ARF2 & $\begin{array}{l}\text { Small Angle } \\
\text { Generator }\end{array}$ & Matrix & 10 arc minutes & 0.1 arc second \\
\hline \multirow[t]{3}{*}{ ARF3 } & Autocollimator & Davidson & 10 arc seconds & 0.15 arc second \\
\hline & & Nikon & 20 arc minutes & $\begin{array}{l}0.3 \text { arc second }+ \\
0.25 \% \text { of measured angle }\end{array}$ \\
\hline & & Hilger Watts & 10 arc minutes & $\begin{array}{l}0.5 \text { arc second }= \\
0.25 \% \text { of measured angle }\end{array}$ \\
\hline ARF4 & $\begin{array}{l}\text { Comparison } \\
\text { Autocollimator }\end{array}$ & Davidson & 120 arc seconds & $\begin{array}{l}0.3 \text { arc second }+ \\
0.5 \% \text { of measured angle }\end{array}$ \\
\hline ARF5 & Surface Analyzer & Federal/Metrex & $\begin{array}{l}0.024 \text { in. (peak to } \\
\text { peak) }\end{array}$ & $\begin{array}{l}(0.4+1.2 \% \text { of reading }) \text { min. } \\
R_{a}\end{array}$ \\
\hline ARF6 & $\begin{array}{l}\text { Surface Roughness } \\
\text { Standard }\end{array}$ & NIST & $\begin{array}{l}120 \min . R_{a} \\
39.5 \min . R_{a} \\
12.7 \min . R_{a}\end{array}$ & $\begin{array}{l}1.7 \min . R_{a} \\
0.59 \min . R_{a} \\
0.31 \min . R_{a}\end{array}$ \\
\hline ARF7 & Lever-Arm Calibrator & rFM\&T Metrology & 0 to 0.0002 in. & 0.2 min. $+0.5 \%$ of travel \\
\hline ARF8 & $\begin{array}{l}\text { Interference } \\
\text { Microscope }\end{array}$ & Zeiss & 0 to $0.01 \mathrm{in.}$ & $1 \mathrm{~min}$. \\
\hline ARF9 & Plano Interferometer & Davidson & 2 3/4-in. diameter & $2 \mathrm{~min}$. \\
\hline ARF10 & $\begin{array}{l}\text { Standard Optical } \\
\text { Flats (set of } 3 \text { ) }\end{array}$ & Do All & 12-in. diameter & Flat within 4 min. \\
\hline ARF11 & $\begin{array}{l}\text { Polychromatic } \\
\text { Interference Fringe } \\
\text { Viewer }\end{array}$ & Strang & NA & $1 \mathrm{~min}$. \\
\hline
\end{tabular}




\section{MASS, FORCE, AND TORQUE AND VOLUMETRIC \\ Mass Measurement}

Mass measurements are made by comparison to master weights or by direct weighing using eleven precision balances. The master weights are calibrated through the NIST Mass Measurement Assurance Program. Metrology also has the capability to perform extremely precise weighing on 1-2-3-5 decade progressions over the range from $1 \mathrm{mg}$ to $5 \mathrm{~kg}$.

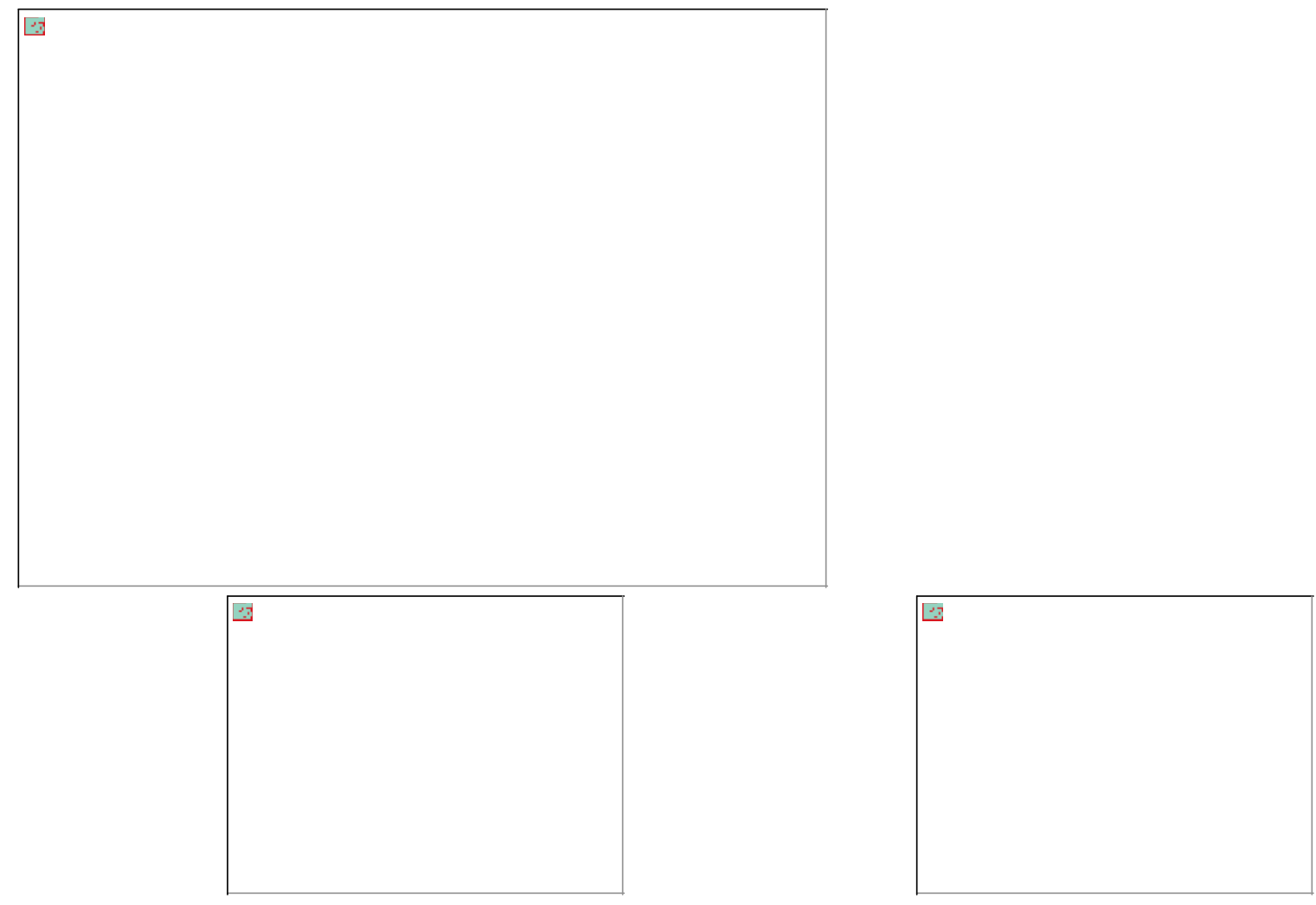

\section{Force Measurement}

Force transducers up to 2400-lbf capacity are measured using weight sets or dead weight testers, which are certified in force units in our Mass lab. Larger force devices are measured by comparison to NIST-calibrated proving rings using a universal force tester.

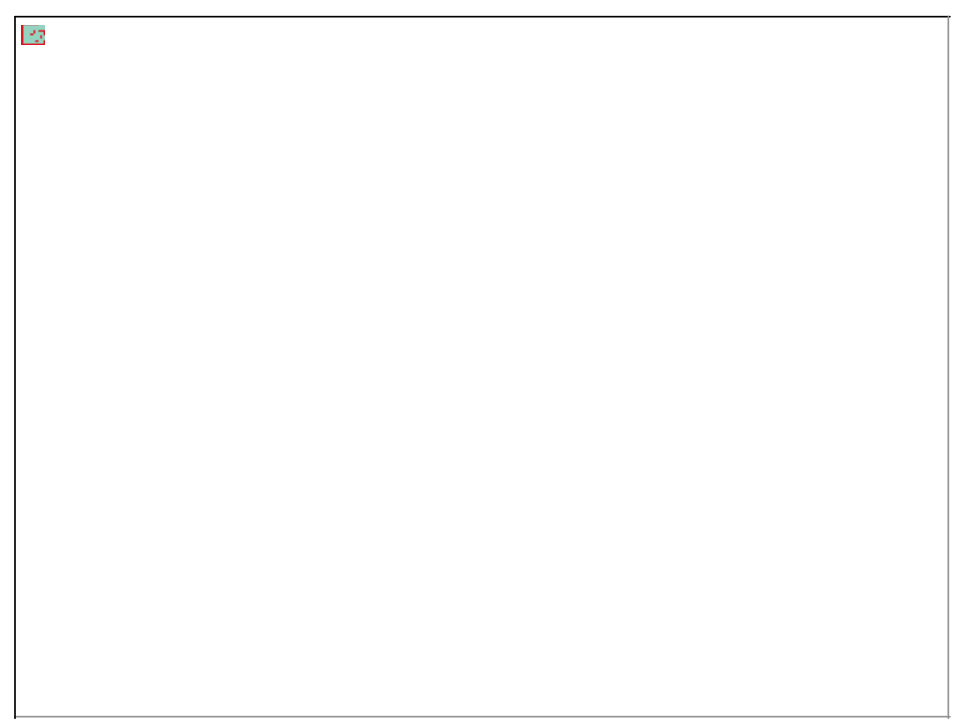




\section{Proving Ring Calibration}

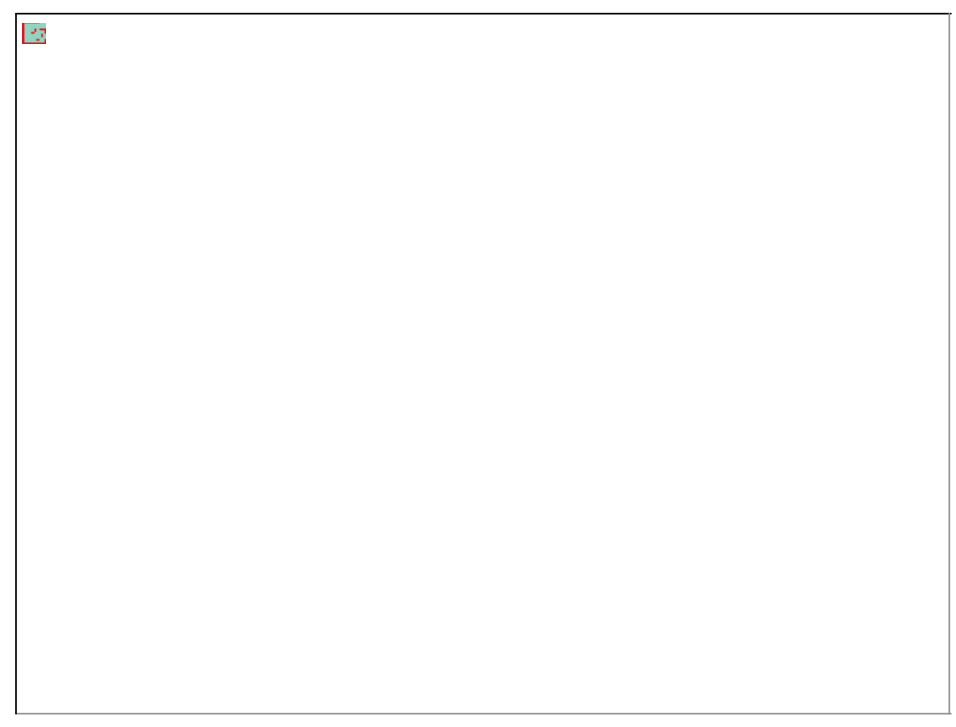

Dead Weight Force Calibration 


\section{Torque Measurement}

Torque transducers are measured using weights, which are certified in force units in our Mass lab and lever arms of known length. The lever arms are calibrated on a coordinate measuring machine using a helium-neon laser as a standard.

Type
Range

Measuring Uncertainty $( \pm)(k=2)$

\section{Laboratory Glassware Volume}

Laboratory glassware volume is measured by the gravimetric method using precision balances and distilled water. 


\section{Laboratory Glassware Volumetric Measurement Capability}

\begin{tabular}{|lll|}
\hline Type & Range & Measuring Uncertainty ( $\mathbf{\pm})(\mathbf{k = 2})$ \\
\hline $\begin{array}{l}\text { Laboratory Glassware Volume } \\
\text { Burets }\end{array}$ & & \\
Volumetric Pipets & 10 to $100 \mathrm{~mL}$ & NIST or ASTM Class A, B \\
Measuring Pipets & 0.5 to $100 \mathrm{~mL}$ & NIST or ASTM Class A, B \\
Volumetric Flasks & 1 to $30 \mathrm{~mL}$ & NIST or ASTM Class A, B \\
& 1 to $5000 \mathrm{~mL}$ & NIST Class A, B \\
Graduated Cylinders & 5 to $2000 \mathrm{~mL}$ & ASTM Class A, B \\
& 5 to $2000 \mathrm{~mL}$ & NIST or ASTM Class A, B \\
\hline
\end{tabular}

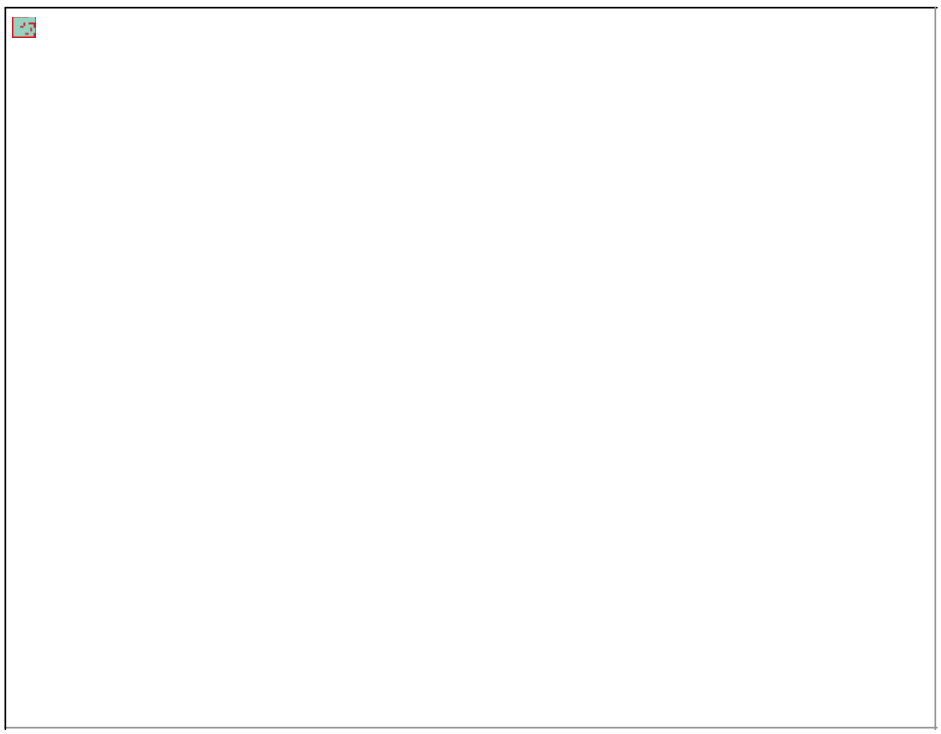

Mass, Force, and Torque Traceability 
Mass, Force, and Torque Standards

\begin{tabular}{|c|c|c|c|c|}
\hline Code & Description & Manufacturer & Range & Uncertainty (?) (k=2) \\
\hline \multirow[t]{3}{*}{ MF1 } & \multirow[t]{3}{*}{ Mass Standards } & $\begin{array}{l}\text { Troemner, } \\
\text { Rice Lake }\end{array}$ & $1 \mathrm{mg}$ to $100 \mathrm{~g}$ & 0.00027 to $0.018 \mathrm{mg}$ \\
\hline & & Troemner & $200 \mathrm{~g}$ to $20000 \mathrm{~g}$ & 0.024 to $20 \mathrm{mg}$ \\
\hline & & Troemner & $1 \mathrm{lb}$ to $50 \mathrm{lb}$ & 2 ppm \\
\hline \multirow[t]{2}{*}{ MF2 } & \multirow[t]{2}{*}{ Proving Rings } & \multirow[t]{2}{*}{ Morehouse } & 3000 to $100,000 \mathrm{lbf}$ & $\begin{array}{l}0.015 \text { to } 0.017 \% \text { of } \\
\text { range }\end{array}$ \\
\hline & & & $300,000 \mathrm{lbf}$ & $0.03 \%$ of range \\
\hline MF3 & Reference Load Cell & BLH & $500,000 \mathrm{lbf}$ & $500 \mathrm{lbf}$ \\
\hline MF4 & Transfer Load Cells & Various & 0 to $240,000 \mathrm{lbf}$ & $0.05 \%$ F.S. $+0.1 \%$ load \\
\hline \multirow[t]{11}{*}{ MF5 } & Balances & Mettler Toledo & 0 to $6.1 \mathrm{~g}$ & Comparison \\
\hline & \multirow{10}{*}{$\begin{array}{l}\text { (uncertainties listed } \\
\text { are for direct } \\
\text { weighing) }\end{array}$} & Mettler Toledo & 0 to $22 \mathrm{~g}$ & $5 \mathrm{ppm}+0.01 \mathrm{mg}$ \\
\hline & & Mettler Toledo & 0 to $111 \mathrm{~g}$ & Comparision \\
\hline & & Mettler Toledo & 0 to $205 \mathrm{~g}$ & $3 \mathrm{ppm}+0.1 \mathrm{mg}$ \\
\hline & & Mettler Toledo & 0 to $1109 \mathrm{~g}$ & Comparison \\
\hline & & Mettler Toledo & 0 to $2300 \mathrm{~g}$ & $5 \mathrm{ppm}$ \\
\hline & & Mettler Toledo & 0 to $10100 \mathrm{~g}$ & $1 \mathrm{ppm}+5 \mathrm{mg}$ \\
\hline & & Mettler Toledo & 0 to $52000 \mathrm{~g}$ & 7 ppm + 40 mg \\
\hline & & Mettler & 0 to $1000 \mathrm{~g}$ & $3 \mathrm{ppm}+0.5 \mathrm{mg}$ \\
\hline & & Mettler & 0 to $5000 \mathrm{~g}$ & 3 ppm + 11 mg \\
\hline & & Mettler & 0 to $60 \mathrm{~kg}$ & $2 \mathrm{~g}$ \\
\hline \multirow[t]{2}{*}{ MF6 } & $\begin{array}{l}\text { Dead Weight } \\
\text { Calibrating Machine }\end{array}$ & Morehouse (modified) & 5 to $300 \mathrm{lbf}$ & $0.01 \%$ of reading \\
\hline & $\begin{array}{l}\text { Dead Weight } \\
\text { Calibrating Machine }\end{array}$ & FM\&T Metrology & 50 to $2400 \mathrm{lbf}$ & $0.01 \%$ of reading \\
\hline MF7 & Torque Standard & FM\&T Metrology & 0 to $700 \mathrm{lbf}-\mathrm{ft}$ & $\begin{array}{l}0.125 \text { to } 0.2 \% \text { of } \\
\text { reading }\end{array}$ \\
\hline MF9 & $\begin{array}{l}\text { Transfer Torque } \\
\text { Standard }\end{array}$ & Norbar & 0 to $700 \mathrm{lbf}-\mathrm{ft}$ & $\begin{array}{l}0.15 \% \text { of range } \\
+0.75 \% \text { of reading }\end{array}$ \\
\hline
\end{tabular}




\section{Vibration}

Standard accelerometers are calibrated at NIST and certified for the transfer of its sensitivity to the Vibration Systems transfer standard accelerometer. The vibration system transfers the sensitivity to other accelerometers. Sensitivity can be determined at ambient temperature or over the range of -70 to $+125^{\circ} \mathrm{C}$. A control standard is measured on the vibration system to verify that the system is functioning properly.

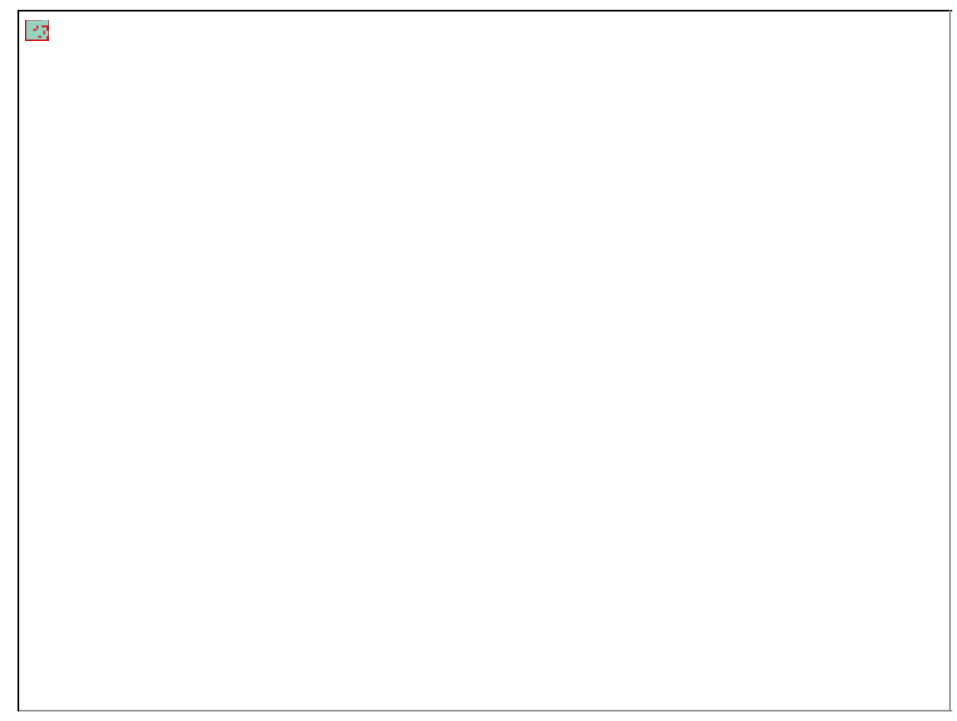

Vibration Calibration System with Environmental Capability 


\section{Mechanical Shock}

The shock standard accelerometer and accelerometers calibrated for shock levels above 10,000 $g$ 's are calibrated using a velocity change shock pulse generator. The area of the shock pulse and the time of flight through a known distance are captured to calculate the sensitivity using the velocity change method. Accelerometers calibrated for shock less than 10,000 g's are calibrated in a back-to-back configuration on a hammer-activated shock pulse generator by comparison to the shock standard accelerometer.

\section{Sound Level}

Calibration of sound level is made by comparison of a sound level meter to a standard pistonphone that is calibrated at NIST.

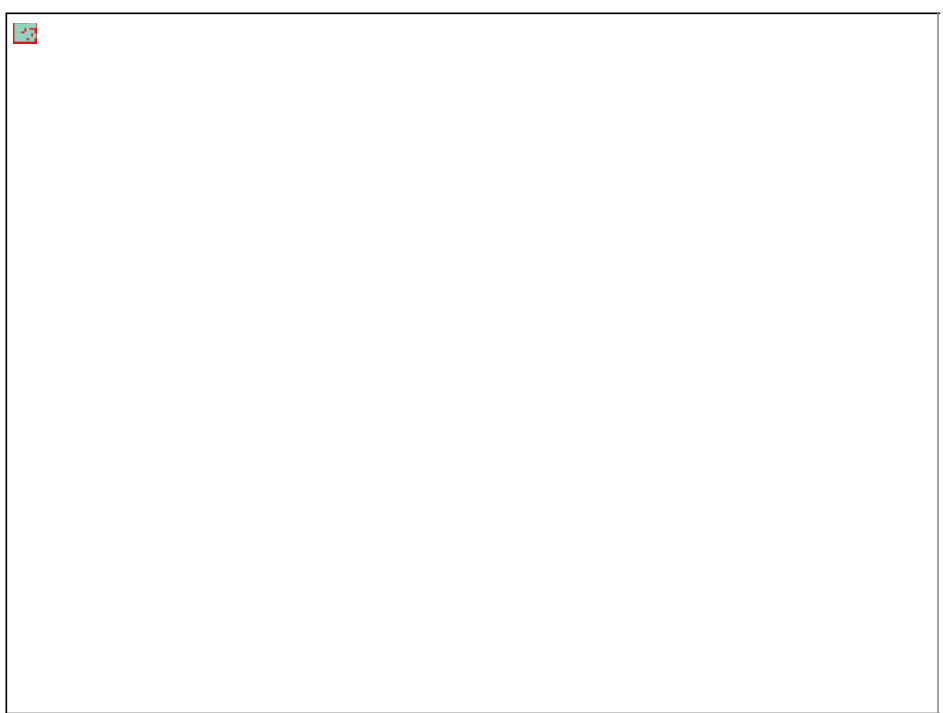

Velocity Change Shock Pulse Generator

Vibration, Acceleration, Shock, Sound Level Measurement Capability

\begin{tabular}{|c|c|c|}
\hline \multicolumn{3}{|c|}{ Mechanical Shock } \\
\hline \multicolumn{3}{|c|}{$\begin{array}{l}\text { The shock standard accelerometer and accelerometers calibrated for shock levels above } 10,000 \\
\text { g's are calibrated using a velocity change shock pulse generator. The area of the shock pulse } \\
\text { and the time of flight through a known distance are captured to calculate the sensitivity using th } \\
\text { velocity change method. Accelerometers calibrated for shock less than } 10,000 \text { g's are calibrate } \\
\text { in a back-to-back configuration on a hammer-activated shock pulse generator by comparison to } \\
\text { the shock standard accelerometer. }\end{array}$} \\
\hline \multicolumn{3}{|c|}{ Sound Level } \\
\hline \multicolumn{3}{|c|}{$\begin{array}{l}\text { Calibration of sound level is made by comparison of a sound level meter to a standard } \\
\text { pistonphone that is calibrated at NIST. }\end{array}$} \\
\hline \multicolumn{3}{|l|}{ 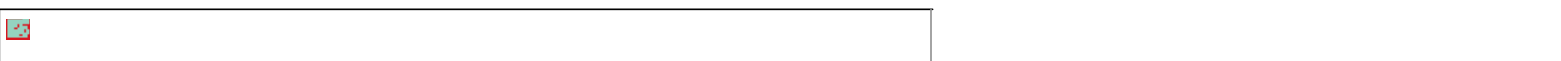 } \\
\hline \multicolumn{3}{|c|}{ Velocity Change Shock Pulse Generator } \\
\hline \multicolumn{3}{|c|}{ Vibration, Acceleration, Shock, Sound Level Measurement Capability } \\
\hline Type & Range & Measuring Uncertainty (?) (k=2) \\
\hline \multirow[t]{2}{*}{ Vibration } & $\begin{array}{l}0.3 \text { to } 75 \mathrm{~g} \text { at } 10 \mathrm{~Hz} \text { to } 10 \mathrm{kHz} \\
\text { at ambient temperature }\end{array}$ & 1.8 to $2.5 \%$ \\
\hline & $\begin{array}{l}10 \mathrm{~g} \text { at } 100 \mathrm{~Hz} \text { to } 10 \mathrm{kHz} \\
\text { at }-65 \text { to }+125^{\circ} \mathrm{C}\end{array}$ & 1.8 to $4.0 \%$ \\
\hline \multirow[t]{2}{*}{ Shock } & $\begin{array}{l}100 \text { to } 25,000 \mathrm{~g} \\
\text { at } 0.05 \text { to } 10 \mathrm{~ms}\end{array}$ & 2.5 to $3.0 \%$ \\
\hline & $\begin{array}{l}>25,000 \mathrm{~g} \\
<0.2 \mathrm{~ms}\end{array}$ & Capability \\
\hline Sound Level & 94 to $124 \mathrm{~dB}$ at $250 \mathrm{~Hz}$ & $0.5 \mathrm{~dB}$ \\
\hline
\end{tabular}




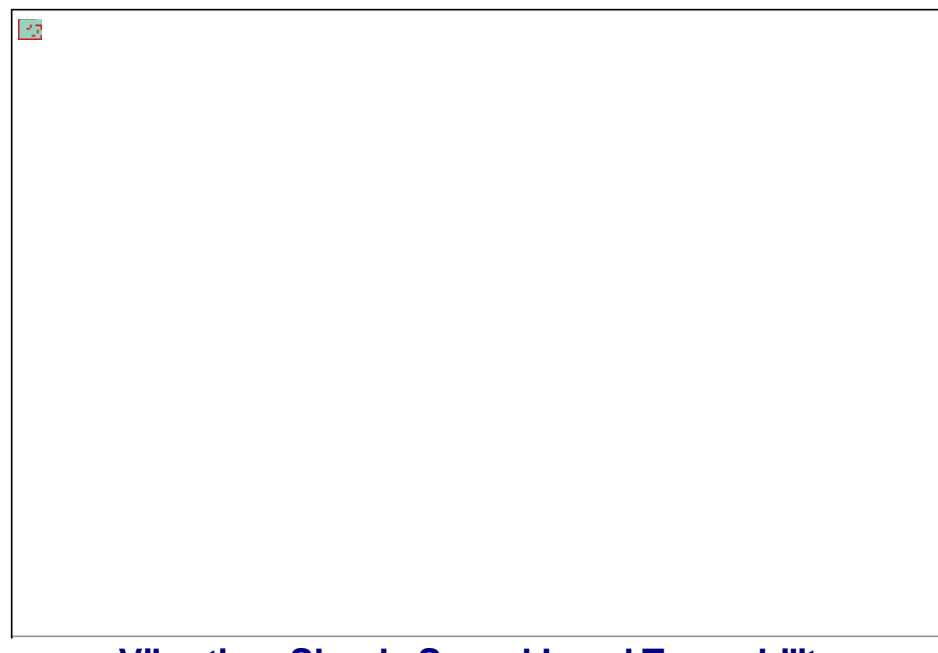

Vibration, Shock, Sound Level Traceability 


\section{Vibration, Acceleration, and Shock Standards}

\begin{tabular}{|c|c|c|c|c|}
\hline Code & Description & Manufacturer & Range & Uncertainty (?) (k=2) \\
\hline SVA1 & $\begin{array}{l}\text { Vibration } \\
\text { Accelerometer } \\
\text { Reference }\end{array}$ & Endevco & $\begin{array}{l}0.3 \text { to } 10 \mathrm{~g} \\
10 \mathrm{~Hz} \text { to } 10 \mathrm{kHz}\end{array}$ & 1 to $2 \%$ \\
\hline SVA2 & $\begin{array}{l}\text { Vibration } \\
\text { Accelerometer } \\
\text { Transfer Standard }\end{array}$ & $\begin{array}{l}\text { Unholtz } \\
\text { Dickie }\end{array}$ & $\begin{array}{l}0.3 \text { to } 10 \mathrm{~g} \\
10 \mathrm{~Hz} \text { to } 10 \mathrm{kHz}\end{array}$ & 1.8 to $2.5 \%$ \\
\hline SVA3 & Vibration System & FM\&T & $\begin{array}{l}0.3 \text { to } 75 \mathrm{~g} \\
10 \mathrm{~Hz} \text { to } 10 \mathrm{kHz}\end{array}$ & $\begin{array}{l}\text { Used only with other } \\
\text { calibrated measuring } \\
\text { standards }\end{array}$ \\
\hline SVA4 & $\begin{array}{l}\text { Shock } \\
\text { Accelerometer } \\
\text { Standard }\end{array}$ & Endevco & 10 to $10,000 \mathrm{~g}$ & $3 \%$ \\
\hline SVA5 & $\begin{array}{l}\text { Back to Back Shock } \\
\text { System }\end{array}$ & FM\&T Metrology & 100 to $10,000 \mathrm{~g}$ & $\begin{array}{l}\text { Used only with other } \\
\text { calibrated measuring } \\
\text { standards }\end{array}$ \\
\hline SVA6 & $\begin{array}{l}\text { Velocity Change } \\
\text { Shock System }\end{array}$ & FM\&T Metrology & 500 to $>25,000 \mathrm{~g}$ & 2.5 to $3.0 \%$ \\
\hline SVA7 & $\begin{array}{l}\text { Time Interval } \\
\text { Counter }\end{array}$ & $\begin{array}{l}\text { Stanford Research } \\
\text { Systems }\end{array}$ & $\begin{array}{l}100 \mathrm{msec} \text { to } \\
10 \mathrm{sec}\end{array}$ & $0.05 \%$ of reading \\
\hline SVA8 & $\begin{array}{l}\text { Coordinate } \\
\text { Measuring Machine }\end{array}$ & Brown \& Sharp & 0 to $0.5 \mathrm{in.}$ & \pm 0.0003 in. from nominal \\
\hline SVA9 & $\begin{array}{l}\text { Standard } \\
\text { Pistonphone }\end{array}$ & $\mathrm{B}$ and $\mathrm{K}$ & $124 \mathrm{~dB}$ at $250 \mathrm{~Hz}$ & $0.25 \mathrm{~dB}$ \\
\hline SVA10 & Capacitance Meter & Data Precision & to $1 \mathrm{mF}$ & $\begin{array}{l}0.1 \% \text { of reading } \\
+1 \text { digit }\end{array}$ \\
\hline SVA11 & $\begin{array}{l}\text { Temperature } \\
\text { Indicators }\end{array}$ & Keithley & $-65 ? C$ to $+125 ? C$ & $1 ? \mathrm{C}$ \\
\hline
\end{tabular}




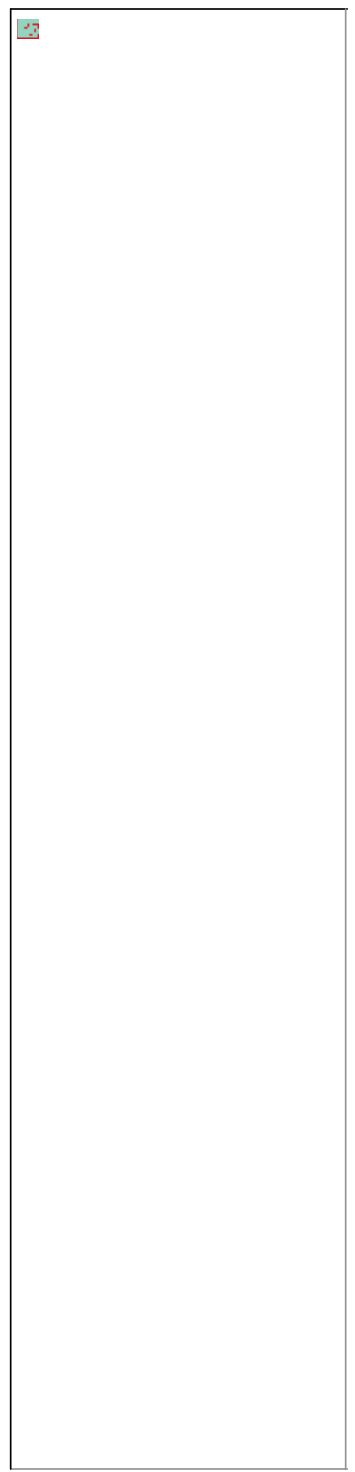

\section{TEMPERATURE, HUMIDITY}

\section{Temperature}

Temperature measurements in Metrology are based both on the International Temperature Scale of 1990 (ITS-90) and the International Practical Temperature Scale of 1968 (IPTS-68). IPTS-68 capabilities will be maintained as long as older equipment is used. There are three primary standards at FM\&T for temperature calibration: fixed point cells, the standard platinum resistance thermometer (SPRT), and the platinum $10 \%$ rhodium versus platinum thermocouple (type S). 


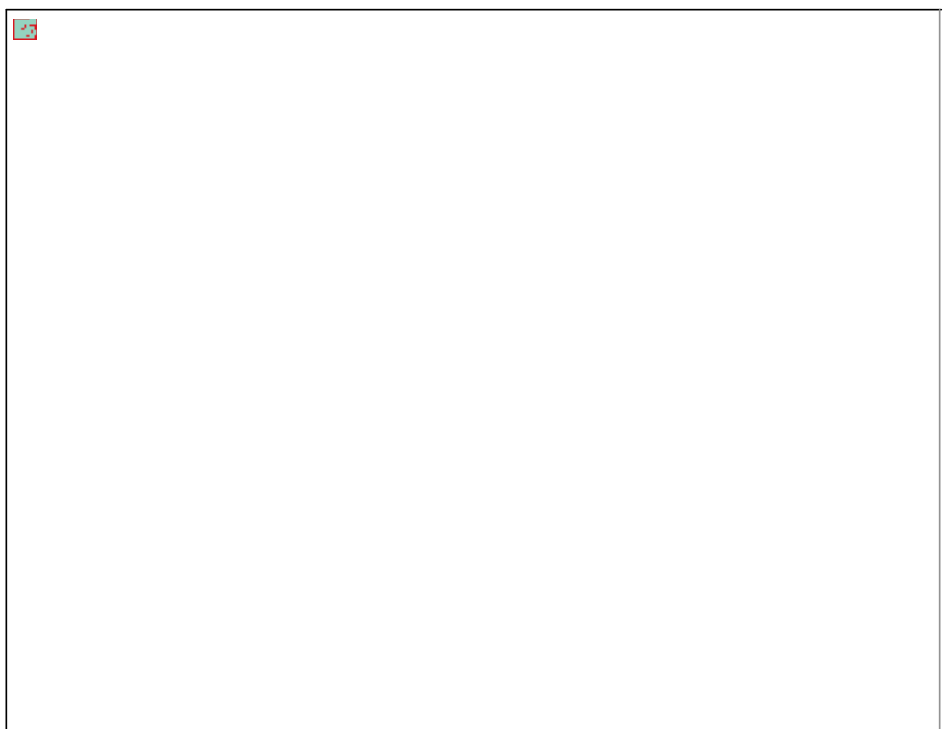

SPRT Calibration Using a Fixed Point Temperature Cell 
The SPRT covers the range from -180 to $500^{\circ} \mathrm{C}$ and is certified to an accuracy of $\pm(0.01$ to $0.05^{\circ} \mathrm{C}$ ). The type $S$ thermocouple covers the range from 0 to $1450^{\circ} \mathrm{C}$ and is certified to an accuracy of $\pm\left(0.5^{\circ} \mathrm{C}\right.$ or $0.2 \%$ of reading), whichever is greater.

Temperature environments for calibrations are created with two stirred baths, a horizontal tube furnace, and fixed point temperature cells. The first stirred bath contains Fluorinert and covers the range from -100 to $+140^{\circ} \mathrm{F}$. The second bath contains silicon oil and covers the range from 70 to $500^{\circ} \mathrm{F}$. Both baths are used to calibrate thermocouples, SPRTs, thermistors, liquid-in-glass thermometers, and some solid state sensors. The horizontal tube furnace covers the range from 73 to $2700^{\circ} \mathrm{F}$ and is used to calibrate different types of thermocouples in air. Fixed-point temperature cells make possible very accurate single point temperature measurements for SPRTs and thermocouples. These cells are (temperatures in ITS-90 scale) Mercury $\left(-38.8344^{\circ} \mathrm{C}\right)$, Water $\left(0.01^{\circ} \mathrm{C}\right)$, Gallium $\left(29.7646^{\circ} \mathrm{C}\right)$, Indium $\left(156.5985^{\circ} \mathrm{C}\right)$, Tin $\left(231.928^{\circ} \mathrm{C}\right)$, and Zinc $\left(419.527^{\circ} \mathrm{C}\right)$. 


\section{Humidity}

Humidity calibrations are performed with two instruments. The first is a frost point generator capable of generating frost points from $-75^{\circ} \mathrm{C}$ to $0^{\circ} \mathrm{C} \pm 0.5^{\circ} \mathrm{C}$. The second is a two-pressure system that can generate humidity from $5 \%$ to $95 \% \mathrm{RH} \pm 0.5 \% \mathrm{RH}$.

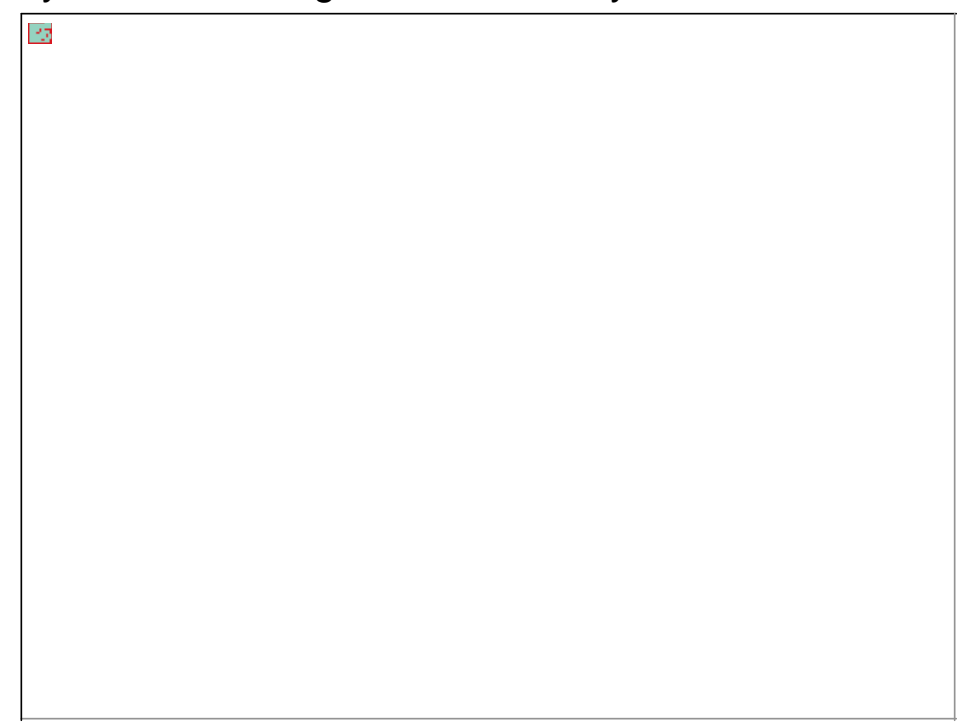

\section{Humidity Calibration Using the Two-Pressure Method}

The dew/frost point temperature and the ambient air temperature of the moist air are measured to determine absolute and relative humidity. Air flow through the test chamber can be varied from 0 to 140 slpm. 
Temperature, Humidity Measurement Capability

\begin{tabular}{|l|l|l|}
\hline Type & Range & Measuring Uncertainty (?) (k=2) \\
\hline Temperature & $-183 ? \mathrm{C}$ to $+420 ? \mathrm{C}$ & 0.005 ? to 0.02 ? \\
& $420 ? \mathrm{C}$ to $1093 ? \mathrm{C}$ & $0.4 \%$ of reading \\
\hline Fixed Point & -38.8344 C & 0.001 ? \\
& 0.01 ? & $0.0005 ? \mathrm{C}$ \\
& $29.7646 ? \mathrm{C}$ & $0.0005 ? \mathrm{C}$ \\
& $156.5985 ? \mathrm{C}$ & $0.001 ? \mathrm{C}$ \\
& $231.928 ? \mathrm{C}$ & $0.002 ? \mathrm{C}$ \\
& $419.527 ? \mathrm{C}$ & $0.002 ? \mathrm{C}$ \\
\hline Humidity & $-75 ? \mathrm{C}$ to $0.0 ? \mathrm{C}$ & $0.5 ? \mathrm{C}$ \\
& $5 \% \mathrm{RH}$ to $95 \% \mathrm{RH}$ & $0.5 \% \mathrm{RH}$ \\
\hline
\end{tabular}




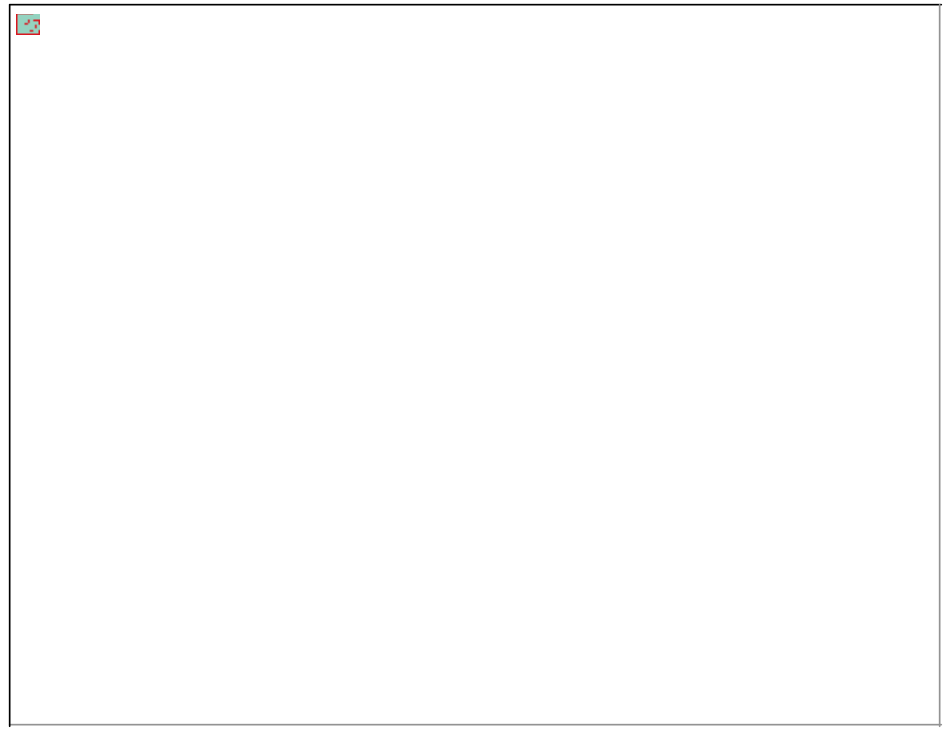

Temperature, Humidity Calibration Traceability 
Temperature, Humidity Standards

\begin{tabular}{|c|c|c|c|c|}
\hline Code & Description & Manufacturer & Range & Uncertainty (?) (k=2) \\
\hline TH1 & $\begin{array}{l}\text { Standard Platinum } \\
\text { Resistance Thermometer }\end{array}$ & Leeds \& Northrup & $\begin{array}{l}-186 \text { to } 0 ? C \\
-40 \text { to } 420 ? C\end{array}$ & $\begin{array}{l}0.02 ? \mathrm{C} \\
0.005 ? \mathrm{C}\end{array}$ \\
\hline TH2 & $\begin{array}{l}\text { Platinum - } \\
\text { Platinum 10\% } \\
\text { Rhodium } \\
\text { Thermocouple }\end{array}$ & Leeds \& Northrup & 0 to 1450 ?C & $\begin{array}{l}0.5 ? \mathrm{C} \text { or } 0.2 \% \text { of reading } \\
\text { (whichever is greater) }\end{array}$ \\
\hline \multirow[t]{7}{*}{ TH3 } & Fixed Temperature Points & & & \\
\hline & Mercury & Isotech & $-38.8344 ? C$ & $0.001 ? \mathrm{C}$ \\
\hline & TP Water & Jarrett & $0.01 ? \mathrm{C}$ & $0.0005 ? \mathrm{C}$ \\
\hline & Gallium & Isotech & $29.7646 ? \mathrm{C}$ & $0.0005 ? \mathrm{C}$ \\
\hline & Indium & Hart Scientific & 156.5985?C & $0.001 ? \mathrm{C}$ \\
\hline & Tin & Isotech & 231.928?C & $0.002 ? \mathrm{C}$ \\
\hline & Zinc & Hart Scientific & $419.527 ? \mathrm{C}$ & $0.002 ?$ \\
\hline \multirow[t]{2}{*}{ TH4 } & Frost Point Generator & Thunder Scientific & -70 to $0 ? \mathrm{C}$ & $0.5 ? \mathrm{C}$ \\
\hline & Two-Pressure Generator & Thunder Scientific & 5 to $95 \% \mathrm{RH}$ & $0.5 \% \mathrm{RH}$ \\
\hline TH7 & Resistance Ratio Bridge & ASL & 0 to 1.2 & $5 \mathrm{ppm}$ \\
\hline TH8 & DVM & Keithley & 0 to $1000 \mathrm{Vdc}$ & $\begin{array}{l}0.015 \% \text { of reading } \\
+4 \text { digits }\end{array}$ \\
\hline
\end{tabular}




\section{GAS, LIQUID}

\section{Pressure}

Pressure gages are calibrated using dead-weight piston gages. The effective area of the 0 to 500 psi reference is determined by NIST. The effective area of the 0 to 15,000 psi reference is determined by PSL. The effective area of the 0 to 100,000 psi reference is determined at FM\&T with NIST traceable standards. True mass for each reference is determined using the NIST Mass MAP program.

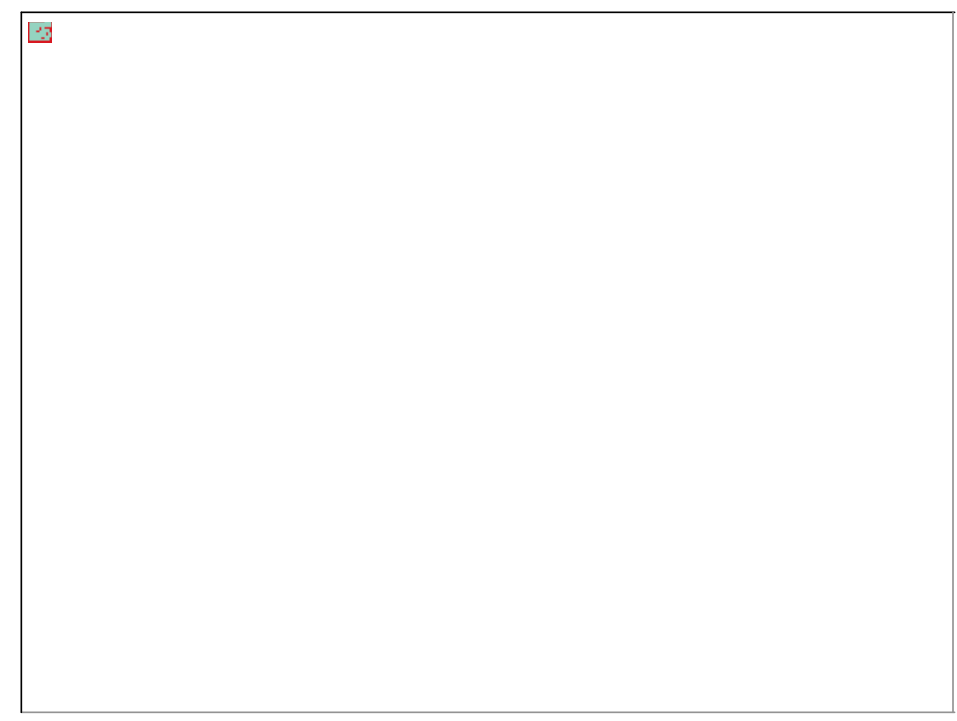

30,000 psig Gas Pressure Calibration 


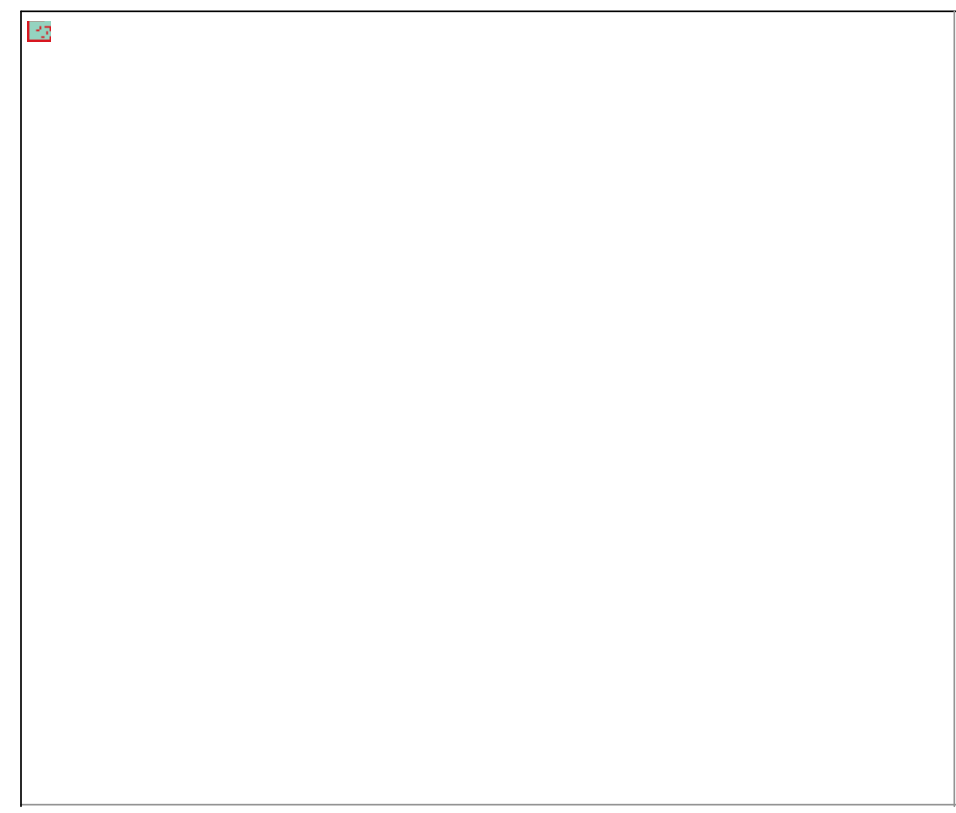

Pressure Calibration Using Controlled Clearance Dead-Weight Piston Gage 


\section{Vacuum}

Vacuum calibrations at or below $10^{-3} \mathrm{mmHg}$ are performed using a molecular drag gage, sometimes called a spinning rotor gage (SRG). The SRG is calibrated by NIST. Orfice ratioing is used to achieve calibrations below $5 \times 10^{-6}$ Torr with an SRG.

Vacuum calibrations above $5 \times 10^{-3} \mathrm{mmHg}$ are performed using either a capacitance manometer or digital Quartz manometer, depending upon the range of the gage. The manometers are calibrated using a PSL-certified dead weight piston gage.

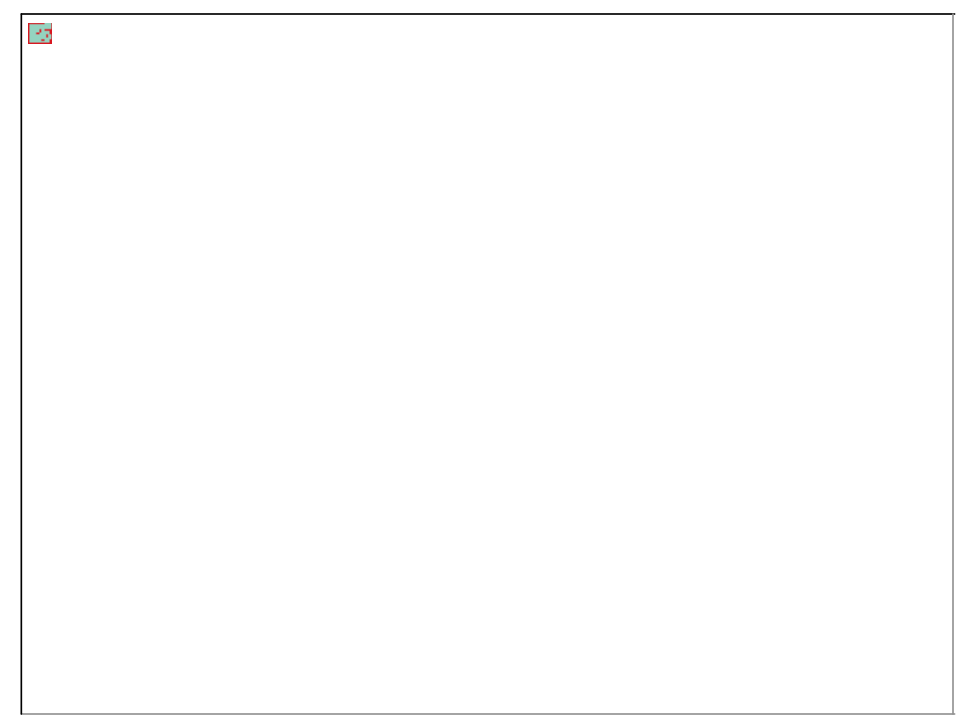

\section{Vacuum Gage Calibration}




\section{Air Velocity}

Air velocity meters are calibrated using a certified wind tunnel. The wind tunnel is calibrated using NIST-certified hot wire anemometer and pitot tube.

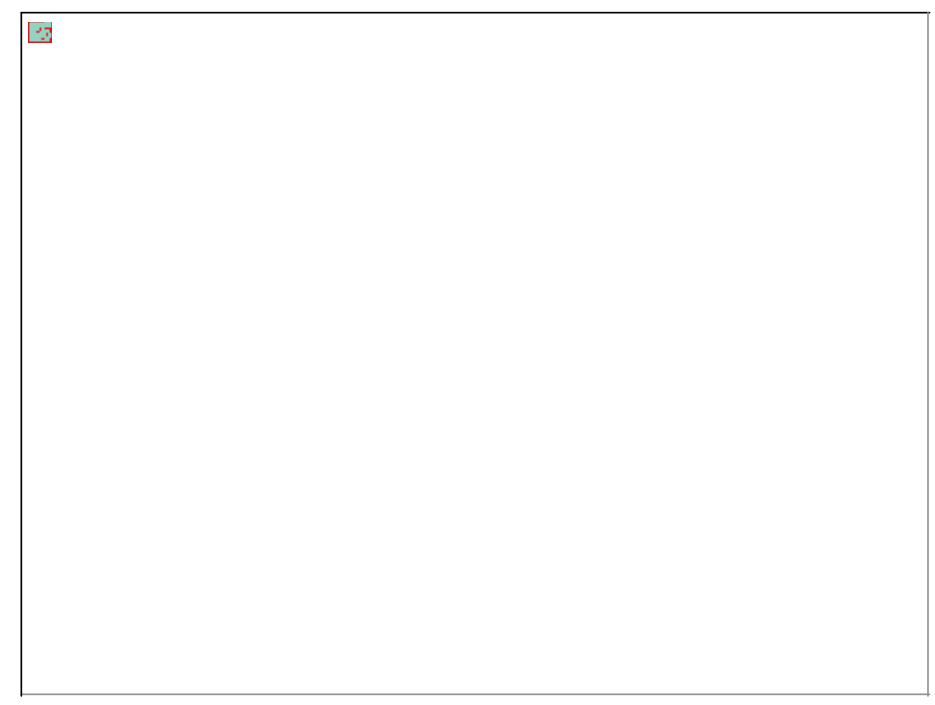

Air Velocity Calibration 


\section{Gas Leaks}

Gas leak devices are calibrated by making direct comparisons to PSL-certified leaks on a mass spectrometer or using the pressure, volume, temperature (PVT) technique. All measurement parameters of the PVT technique are certified and NIST traceable. A precision gas analyzer is used to evaluate the composition of the leak gas.

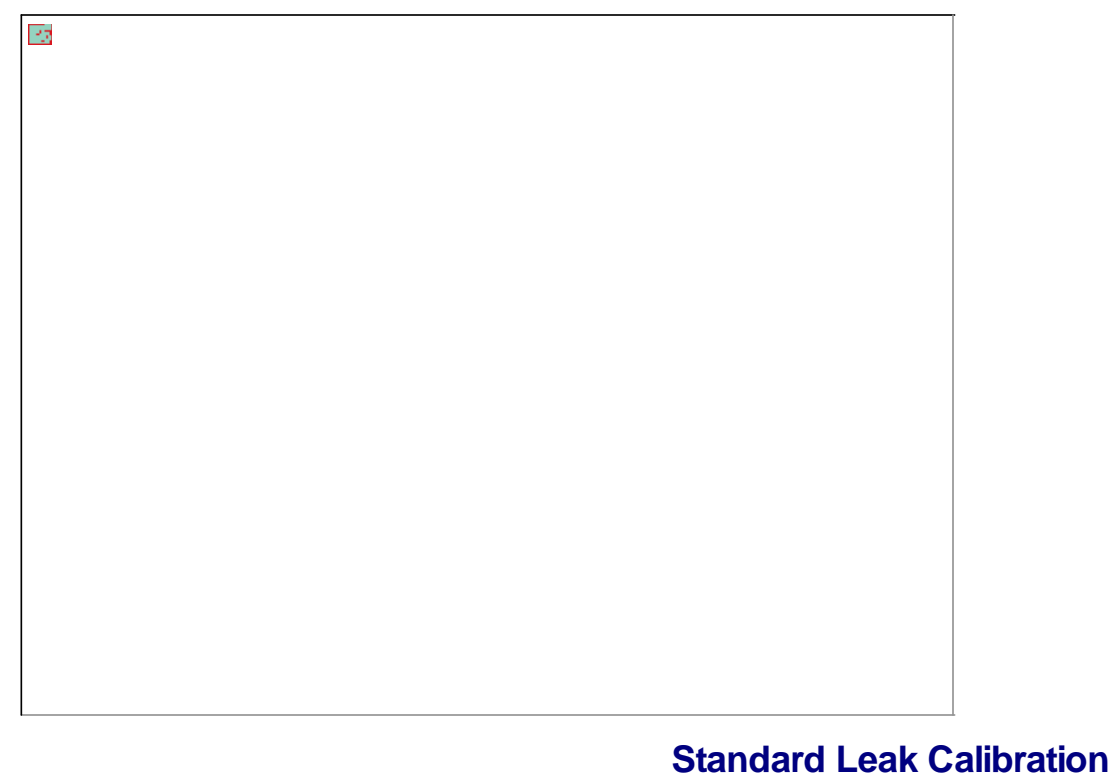

\section{Gas Flow}

Gas flowmeters are calibrated by direct comparisons to PSL-certified flow meters or volumetric displacement devices. Volume, time, pressure, and temperature measurements are combined to obtain a value of flow. All measurement parameters are certified and NIST traceable.

\section{Viscosity}

Viscometers are calibrated using standard viscosity oils obtained from the Cannon Instrument Company, an approved CCL source. 


\section{Gas, Liquid Measurement Capability}

\begin{tabular}{|c|c|c|}
\hline Type & Range & Uncertainty (?) (k=2) \\
\hline Pressure & $\begin{array}{l}\frac{\text { Absolute }}{10^{-8} \text { to } 10^{-4} \text { Torr }} \\
10^{-3} \text { to } 0.05 \text { Torr } \\
1 \text { to } 10 \text { Torr } \\
10 \text { to } 1100 \text { Torr } \\
0 \text { to } 30 \text { psia } \\
\text { Gage } \\
0.5 \text { to } 1800 \text { psig } \\
600 \text { to } 15,000 \text { psig } \\
15,000 \text { to } 100,000 \text { psig }\end{array}$ & $\begin{array}{l}10 \% \\
(0.0003+0.005 \times \text { reading }) \text { Torr } \\
(0.0005+0.003 \times \text { reading }) \text { Torr } \\
(0.03+0.0002 \times \text { reading }) \text { Torr } \\
(0.01+0.0002 \times \text { reading }) \mathrm{psi} \\
\\
0.025 \% \\
0.05 \% \\
0.05 \%\end{array}$ \\
\hline Air Velocity & $\begin{array}{l}30 \text { to } 250 \mathrm{sfpm} \\
251 \text { to } 1500 \mathrm{sfpm} \\
1501 \text { to } 9500\end{array}$ & $\begin{array}{l}4.5 \mathrm{sfpm}+1 \% \text { of Reading } \\
6.0+1 \% \text { of Reading } \\
30 \mathrm{sfpm}+2 \% \text { of Reading }\end{array}$ \\
\hline Gas Flow & $\begin{array}{l}1 \text { to } 100,000 \mathrm{sccm} \\
50 \text { to } 1800 \mathrm{slpm}\end{array}$ & $\begin{array}{l}1 \% \\
2 \%\end{array}$ \\
\hline Leak Rate & $\begin{array}{l}1 \times 10^{-1} \text { to } 5 \times 10^{-9} \\
\text { standard } \mathrm{cm}^{3} / \mathrm{s} \text { STP } \\
10^{-10} \text { standard } \mathrm{cm}^{3} / \mathrm{s} \text { STP }\end{array}$ & $\begin{array}{l}5 \text { to } 15 \% \\
25 \%\end{array}$ \\
\hline Viscosity & 0.3 to $5,300,000 \mathrm{mPa} \cdot \mathrm{s}$ & 2.5 to $5 \%$ \\
\hline
\end{tabular}

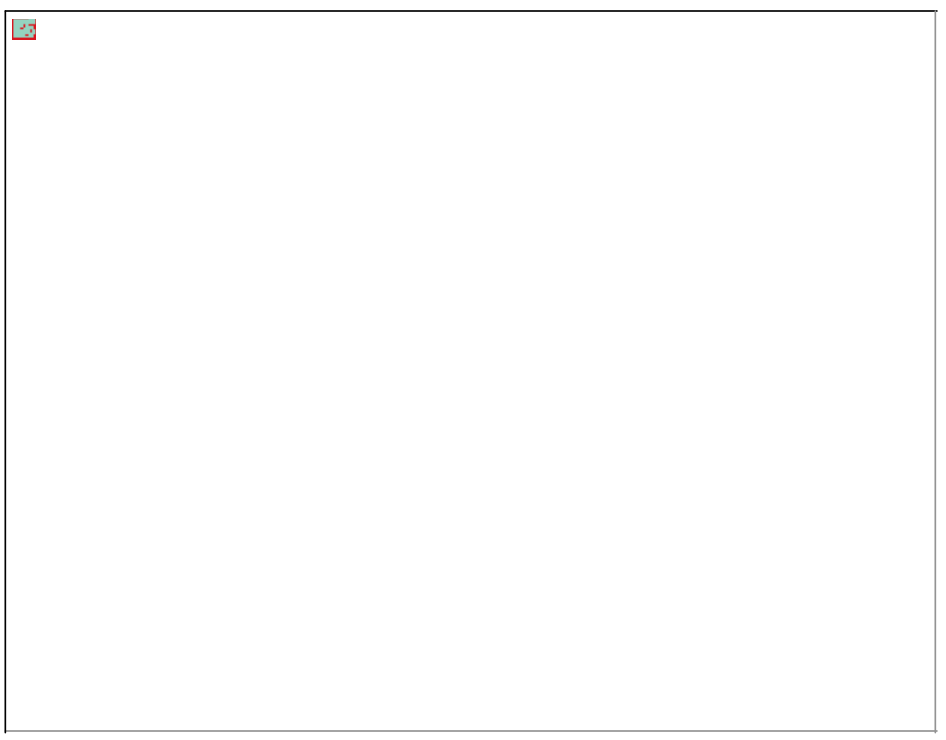

Pressure Calibration Calibration Traceability 


\section{Pressure Standards}

\begin{tabular}{|c|c|c|c|c|}
\hline Code & Description & Manufacturer & Range & Uncertainty (?) (k=2) \\
\hline P1 & Piston Gage & $\begin{array}{l}\text { CEC } \\
\text { DH Instruments }\end{array}$ & $\begin{array}{l}0.2 \text { to } 600 \text { psi } \\
0 \text { to } 30 \text { PSID } \\
20 \text { to } 1800 \text { psi }\end{array}$ & $\begin{array}{l}0.015 \% \\
0.15 \% \\
0.015 \%\end{array}$ \\
\hline P2 & Piston Gages & Ruska & 30 to 15,000 psig & $0.03 \%$ \\
\hline P3 & $\begin{array}{l}\text { Molecular Drag } \\
\text { Gage }\end{array}$ & MKS & $\begin{array}{l}10^{-8} \text { Torr } \\
10^{-7} \text { Torr } \\
10^{-6} \text { Torr } \\
10^{-5} \text { Torr } \\
10^{-4} \text { Torr } \\
10^{-3} \text { Torr } \\
10^{-2} \text { Torr }\end{array}$ & $\begin{array}{l}8 \% \\
8 \% \\
8 \% \\
4 \% \\
3 \% \\
3 \% \\
3 \%\end{array}$ \\
\hline P4 & Digital Quartz & Paroscientific & 0.1 to 1100 Torr & $\begin{array}{l}(0.02+0.0001 \times \text { Reading }) \text { Torr } \\
(0.004+0.0001 \times \text { Reading }) \mathrm{psi}\end{array}$ \\
\hline P5 & $\begin{array}{l}\text { Capacitance } \\
\text { Manometer } \\
\text { (Differential) }\end{array}$ & MKS & $\begin{array}{l}10^{-3} \text { to } 0.05 \text { Torr } \\
0.05 \text { to } 1 \text { Torr } \\
1 \text { to } 1000 \text { Torr }\end{array}$ & $\begin{array}{l}0.0005 \text { Torr } \\
0.001 \text { Torr or } 0.0075 \times \text { Reading } \\
\text { whichever is greater } \\
(0.01+0.00015 \times \text { Reading }) \text { Torr }\end{array}$ \\
\hline P6 & $\begin{array}{l}\text { Controlled-Clearan } \\
\text { DWPG }\end{array}$ & eHarwood & 5000 to $100,000 \mathrm{psi}$ & $0.03 \%$ of Reading \\
\hline P7 & $\begin{array}{l}\text { Capacitance } \\
\text { Manometer } \\
\text { (Absolute) }\end{array}$ & MKS & $\begin{array}{l}10^{-3} \text { to } 0.1 \text { Torr } \\
0.01 \text { to } 10 \text { Torr }\end{array}$ & $\begin{array}{l}(0.5+0.0025 \div \text { Reading }) \% \\
(0.4+0.03 \div \text { Reading }) \%\end{array}$ \\
\hline P8 & $\begin{array}{l}\text { Orifice } \\
\text { (Pressure Ratio) }\end{array}$ & MKS & $\begin{array}{l}100: 1 \\
1000: 1\end{array}$ & $\begin{array}{l}3 \% \\
3 \%\end{array}$ \\
\hline
\end{tabular}




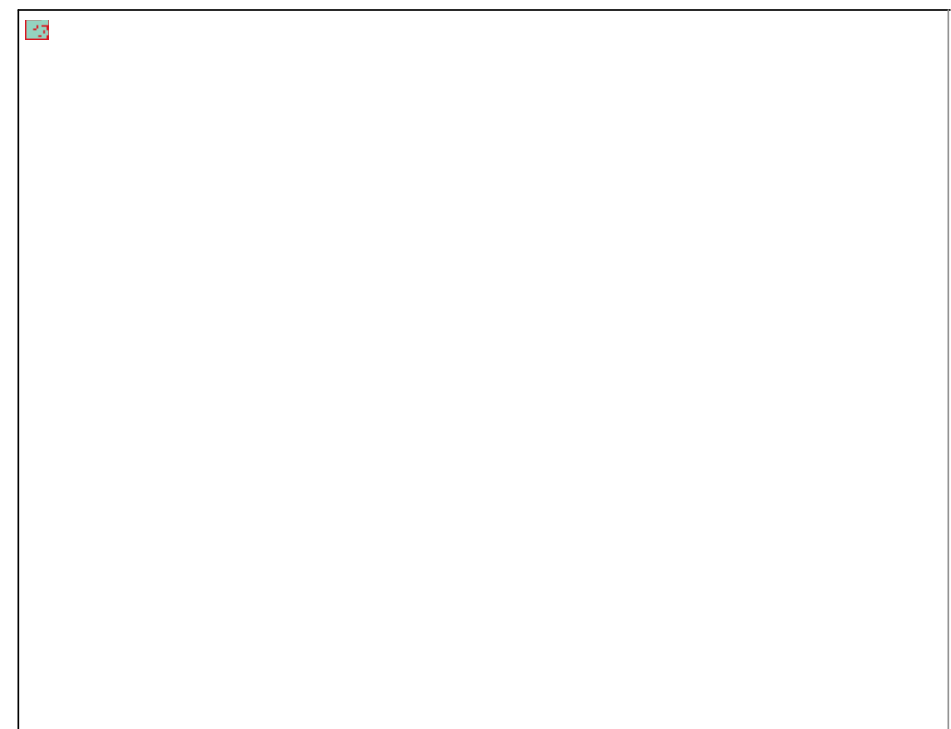

Air Velocity Calibration Traceability

Air Velocity Standards

\begin{tabular}{lllll}
\hline Code & Description & Manufacturer & Range & Uncertainty (?) (k=2) \\
\hline AV1 & Pitot Tube & & 1000 to $9500 \mathrm{sfpm}$ & $\left(1+2375081.6 /\right.$ Reading $\left.^{2}\right) \%$ \\
AV2 & Hot Wire & TSI & 30 to $100 \mathrm{sfpm}$ & $\left(2+1453.7724 /\right.$ Reading $\left.^{2}\right)$ sfpm \\
& Anemometer & & 101 to $1000 \mathrm{sfpm}$ & $\left(7.436+440.86 /\right.$ Reading $\left.^{2}\right)$ sfpm \\
AV3 & Differential & MKS & 0 to 10 Torr & $0.004 \times$ Reading \\
& Pressure Sensor & & 0 to 100 Torr & $0.2 \%$ \\
AV4 & Barometer & Paroscientific & & $0.3 \mathrm{mmHg}$ \\
AV5 & Thermometer & Yellow Springs & & $0.1^{\circ} \mathrm{C}$ \\
AV6 & Humidity Sensor & FM\&T & & $5 \%$
\end{tabular}




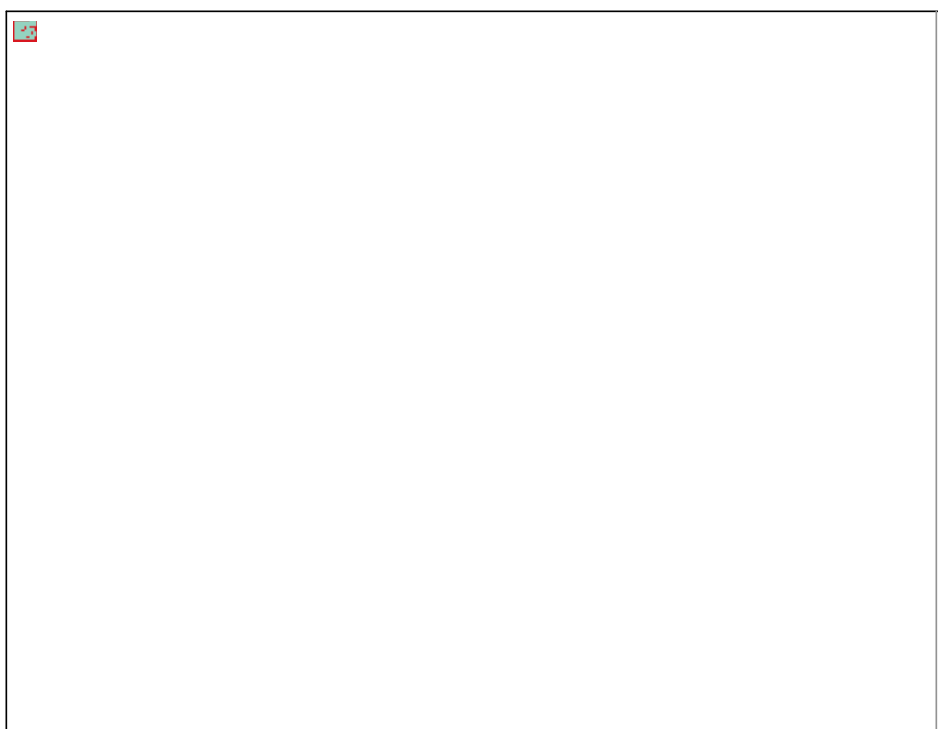

Gas Leak, Flow Rate, Viscosity Calibration Traceability 


\section{Gas Leak, Flow Rate, Viscosity Standards}

\begin{tabular}{|c|c|c|c|c|}
\hline Code & Description & Manufacturer & Range & Uncertainty (?) (k=2) \\
\hline FLV1 & Leak Standard & Veeco/VIC/VTI & $\begin{array}{l}1 \times 10^{-7} \text { to } 1 \times 10^{-6} \mathrm{~cm}^{3} / \mathrm{s} \text { STP } \\
1 \times 10^{-9} \text { to } 9.9 \times 10^{-8} \mathrm{~cm}^{3} / \mathrm{s} \mathrm{STP} \\
2 \times 10^{-10} \text { to } 9.9 \times 10^{-10} \mathrm{~cm}^{3} / \mathrm{s} \mathrm{STP}\end{array}$ & $\begin{array}{l}2 \text { to } 4 \% \\
2 \text { to } 5.5 \% \\
7 \text { to } 10 \%\end{array}$ \\
\hline FLV2 & Leak Detector & $\begin{array}{l}\text { Vacuum } \\
\text { Technology, Inc. }\end{array}$ & $\begin{array}{l}1 \times 10^{-6} \text { to } 1 \times 10^{-9} \mathrm{~cm}^{3} / \mathrm{s} \text { STP } \\
1 \times 10^{-9} \text { to } 2 \times 10^{-10} \mathrm{~cm}^{3} / \mathrm{s} \text { STP }\end{array}$ & $\begin{array}{l}2 \% \\
2 \%\end{array}$ \\
\hline FLV3 & $\begin{array}{l}\text { Laminar } \\
\text { Flowmeter }\end{array}$ & $\begin{array}{l}\text { National } \\
\text { Instrument } \\
\text { Laboratories }\end{array}$ & 1 to 500 slpm & 1 to $2 \%$ \\
\hline FLV4 & Piston Column & George Porter & Volume $400 \mathrm{~cm}^{3}$ & $0.3 \mathrm{~cm}^{3}$ \\
\hline FLV5 & $\begin{array}{l}\text { Floating Piston } \\
\text { Column }\end{array}$ & FM\&T Metrology & 1 to $100,000 \mathrm{SCCM}$ & $0.25 \%$ \\
\hline FLV6 & Timer & Standard Electric & 0 to 999 seconds & $0.1 \%+1$ count \\
\hline FLV7 & $\begin{array}{l}\text { Variable Area } \\
\text { Flowmeter }\end{array}$ & Fisher \& Porter & 8 to $23 \mathrm{sfpm}$ & $0.3 \mathrm{sfpm}$ \\
\hline FLV8 & $\begin{array}{l}\text { Standard } \\
\text { Viscosity Oils }\end{array}$ & $\begin{array}{l}\text { Cannon } \\
\text { Instrument }\end{array}$ & 0.3 to $5,300,000 \mathrm{mPa} \cdot \mathrm{s}$ & 0.58 to $0.83 \%$ \\
\hline FLV9 & $\begin{array}{l}\text { Leak Calibrator } \\
\text { (Rate of pressure } \\
\text { rise) }\end{array}$ & VTI & 0.1 to $1 \times 10^{-7} \mathrm{~cm}^{3} / \mathrm{s}$ STP & 3 to $5 \%$ \\
\hline FLV10 & Volume & Whitey & 25 to $1100 \mathrm{~cm}^{3}$ & $0.1 \%$ \\
\hline FLV11 & Sonic Nozzle & Flow Dyne & 0.2 to $1800 \mathrm{slpm}$ & $1 \%$ \\
\hline
\end{tabular}




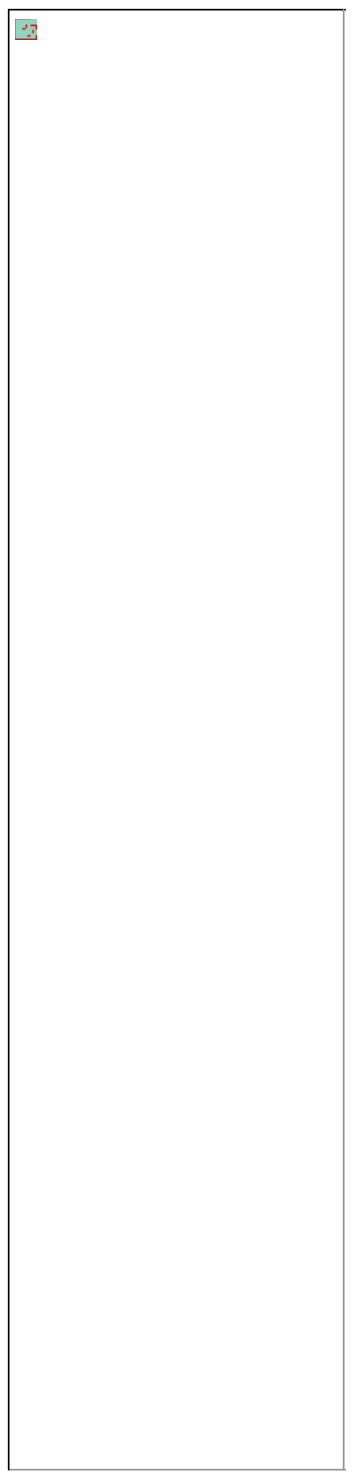

\section{ELECTRICAL}

\section{Electrical Measurement}

\section{Voltage}

The basic reference for DC voltage measurements consists of two groups of zener voltage references. Both groups are re-certified by intercomparison tests with a Josephson array voltage standard from the Primary Standards Laboratory. A precision potentiometer is used for voltage measurements to 10 volts. The potentiometer and a precision divider are used for measurements up to 1500 volts. High voltage dividers calibrated by the Primary Standards Laboratory or by NIST are used for measurements up to 150 kilovolts. 


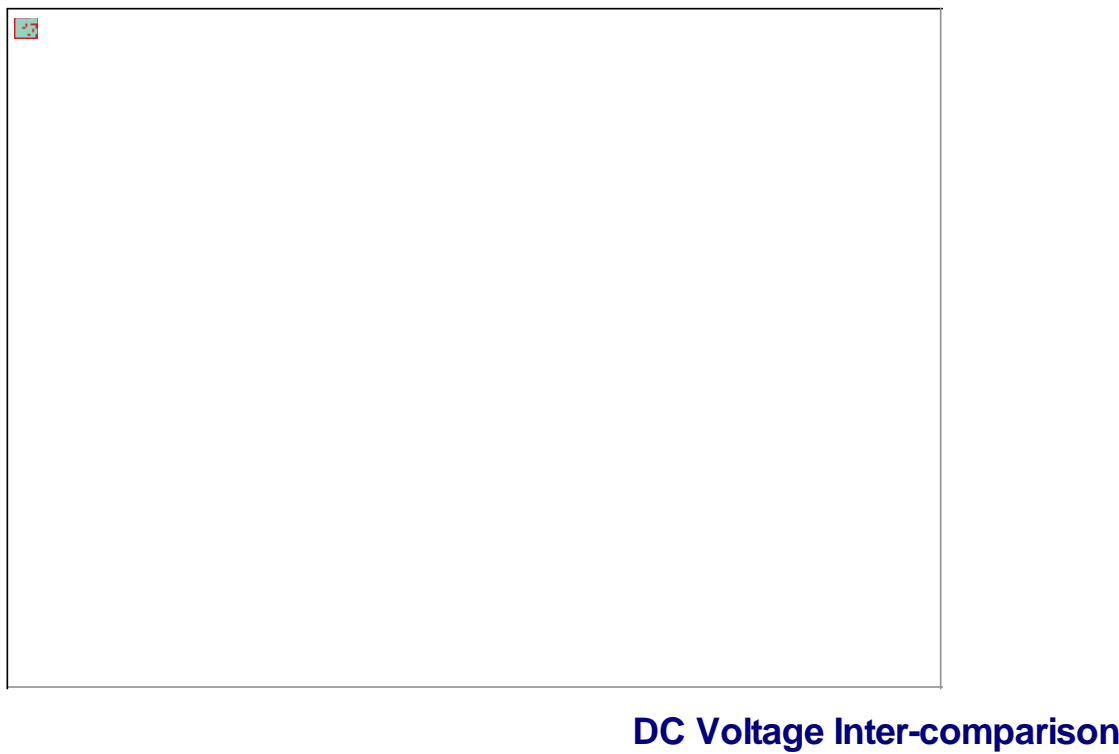




\section{Current}

Measurements of current up to 2 amperes are made using resistance and voltage standards. Shunts calibrated by the Primary Standards Laboratory are used for current measurements from 2 amperes to 300 amperes.

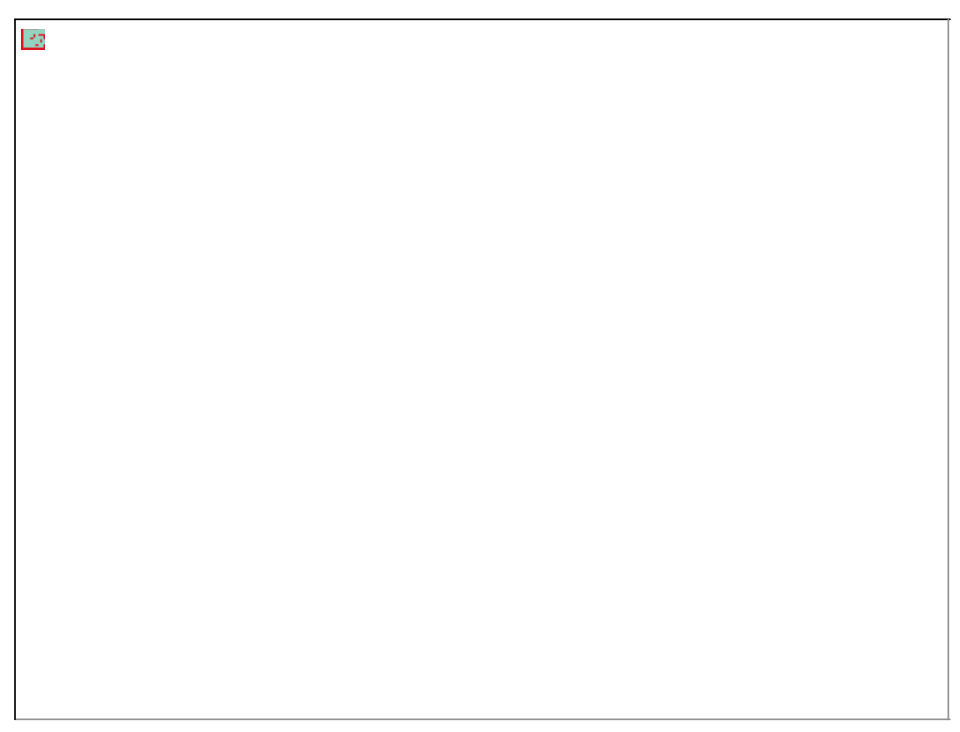

Automated Digital Multimeter Calibration 
Electrical DC Measurement Capability

\begin{tabular}{|c|c|c|}
\hline Type & Range & Measuring Uncertainty (?) ( $k=2)$ \\
\hline DC Voltage & $\begin{array}{l}0 \text { to } 10 \mathrm{~V} \\
10 \text { to } 1500 \mathrm{~V} \\
1.5 \mathrm{kV} \text { to } 10 \mathrm{kV} \\
>10 \mathrm{kV} \text { to } 150 \mathrm{kV}\end{array}$ & $\begin{array}{l}(0.75 \mathrm{ppm}+0.0375 \mathrm{mV}) \\
2.5 \mathrm{ppm} \\
0.02 \% \\
0.028 \%\end{array}$ \\
\hline DC Current & $\begin{array}{l}10^{-10} \mathrm{~A} \\
10^{-9} \mathrm{~A} \\
10^{-8} \mathrm{~A} \\
10^{-7} \text { to } 10^{-6} \mathrm{~A} \\
10^{-5} \text { to } 0.3 \mathrm{~A} \\
>0.3 \text { to } 15 \mathrm{~A} \\
>15 \text { to } 100 \mathrm{~A} \\
>100 \text { to } 500 \mathrm{~A}\end{array}$ & $\begin{array}{l}0.1 \% \\
0.1 \% \\
0.04 \% \\
0.04 \% \\
0.004 \% \\
0.005 \% \\
0.007 \% \\
0.008 \%\end{array}$ \\
\hline DC Resistance & $\begin{array}{l}10^{-4} \text { to } 10^{-1} \mathrm{~W} \\
10^{0} \text { to } 10^{3} \mathrm{~W} \\
10^{3} \text { to } 10^{7} \mathrm{~W} \\
10^{7} \text { to } 10^{8} \mathrm{~W} \\
10^{8} \text { to } 10^{10} \mathrm{~W} \\
10^{10} \text { to } 10^{13} \mathrm{~W}\end{array}$ & $\begin{array}{l}0.6 \mathrm{ppm} \\
0.34 \mathrm{ppm} \\
0.56 \mathrm{ppm} \\
1.52 \mathrm{ppm} \\
0.2 \% \\
0.05 \%\end{array}$ \\
\hline DC Magnetic Flux Density & $\begin{array}{l}\text { Transverse Probe: } \\
20 \text { to } 10,000 \text { Gauss } \\
\text { Axial Probe: } \\
50 \text { to } 2000 \text { Gauss }\end{array}$ & $\begin{array}{l}2 \% \text { to } 4 \% \\
2 \% \text { to } 4 \%\end{array}$ \\
\hline
\end{tabular}




\section{Current and Voltage Standards}

\begin{tabular}{|c|c|c|c|c|}
\hline Code & Description & Manufacturer & Range & Uncertainty (?) (k=2) \\
\hline $\mathrm{DC} 1$ & $\begin{array}{l}\text { Zener Voltage } \\
\text { References }\end{array}$ & Fluke & $\begin{array}{l}1.018 \mathrm{~V} \text { and } \\
10 \mathrm{~V} \text { nominal }\end{array}$ & $0.33 \mathrm{ppm}$ \\
\hline DC2 & Voltage Dividers & $\begin{array}{l}\text { Julie } \\
\text { Fluke }\end{array}$ & $\begin{array}{l}10 \text { to } 100 \mathrm{kV} \\
1 \text { to } 10 \mathrm{kV}\end{array}$ & $\begin{array}{l}0.013 \% \quad \text { (Calibrated by NIST) } \\
0.033 \% \quad \text { (Calibrated by Metrology) }\end{array}$ \\
\hline DC3 & $\begin{array}{l}\text { Precision } \\
\text { Potentiometer }\end{array}$ & \multicolumn{2}{|c|}{ Measurements International0 to $10 \mathrm{~V}$} & $(0.25 \mathrm{ppm}+0.0375 \mathrm{mV})$ \\
\hline DC4 & $\begin{array}{l}\text { Precision Shunt } \\
\text { Boxes }\end{array}$ & Leeds \& Northrup & 0.015 to $15 \mathrm{~A}$ & 33 ppm \\
\hline DC5 & $\begin{array}{l}\text { Precision DC } \\
\text { Current Supply }\end{array}$ & FM\&T Metrology & $\begin{array}{l}1.5 \mathrm{~mA} \text { to } 15 \mathrm{~A} \\
\text { (7 ranges) }\end{array}$ & $(0.02 \%$ or $1 \mathrm{nA})$, whichever is greater \\
\hline DC6 & $\begin{array}{l}\text { Precision DC } \\
\text { Voltage Source }\end{array}$ & Fluke & $\begin{array}{l}0 \text { to } 220 \mathrm{mV} \\
>0.22 \text { to } 220 \mathrm{~V} \\
>220 \text { to } 1100 \mathrm{~V}\end{array}$ & $\begin{array}{l}8 \mathrm{ppm}+3 \mathrm{ppm} \text { of range } \\
8 \mathrm{ppm}+0.5 \mathrm{ppm} \text { of range } \\
9 \mathrm{ppm}+0.5 \mathrm{ppm} \text { of range }\end{array}$ \\
\hline DC7 & Ratio Divider & Guildline & $1: 1$ to $10,000: 1$ & 2 ppm \\
\hline DC8 & Shunt Standards & $\begin{array}{l}\text { Leeds \& Northrup } \\
\text { Guildline }\end{array}$ & $\begin{array}{l}0 \text { to } 15 \mathrm{~A} \\
0 \text { to } 100 \mathrm{~A} \\
0 \text { to } 300 \mathrm{~A} \\
0 \text { to } 500 \mathrm{~A}\end{array}$ & $\begin{array}{l}0.0033 \% \\
0.0066 \% \\
0.0066 \% \\
0.0066 \%\end{array}$ \\
\hline DC9 & $\begin{array}{l}\text { Precision } \\
\text { Digital Multimeter }\end{array}$ & Hewlett-Packard & $\begin{array}{l}0.1 \text { to } 100 \mathrm{~V} \\
0.1 \text { to } 1000 \mathrm{~V}\end{array}$ & $\begin{array}{l}25 \text { ppm (Ratio) } \\
11 \text { ppm to } 25 \text { ppm (DC Voltage) }\end{array}$ \\
\hline
\end{tabular}




\section{Resistance}

The reference for resistance measurements is a Thomas $1 \mathrm{ohm}$ and a $10 \mathrm{kohm}$ standard resistor that are certified by the Sandia Primary Standards Laboratory. These resistors in conjunction with an automated resistance system are used to measure resistance from $0.001 \mathrm{ohm}$ to 100 megohm. From 100 megohm to 10 teraohm, resistance measurements are accomplished using a high resistance meter.

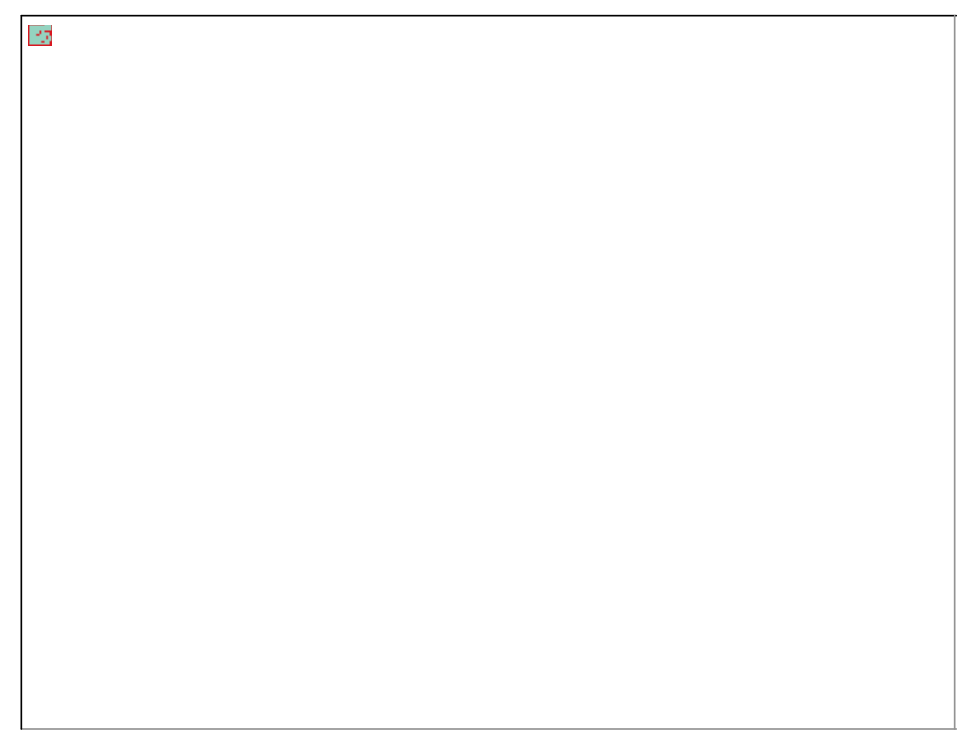

Automated Resistance Measuring System

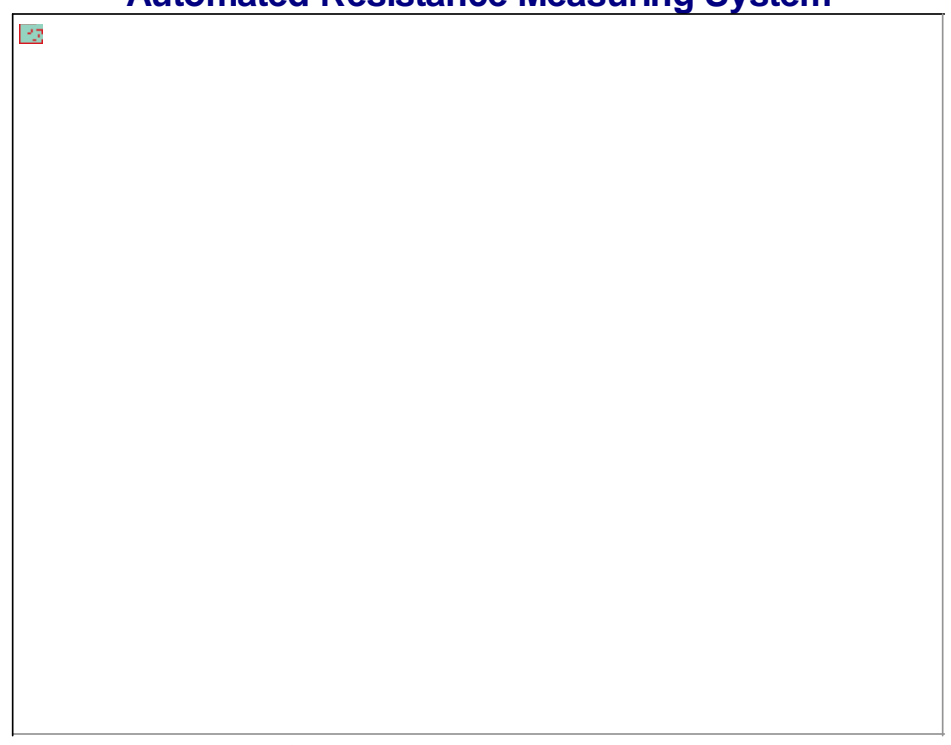

DC Resistance Traceability 


\section{Resistance and Ratio Standards}

\begin{tabular}{lllll}
\hline Code & Description & Manufacturer & Range & Uncertainty (?) (k=2) \\
\hline RES1 & Master Resistors & $\begin{array}{l}\text { Leeds \& Northrup } \\
\text { ESI }\end{array}$ & $\begin{array}{l}1 \mathrm{~W} \\
10 \mathrm{~kW}\end{array}$ & $\begin{array}{l}0.333 \mathrm{ppm} \\
0.25 \mathrm{ppm}\end{array}$ \\
RES3 & $\begin{array}{l}\text { High Resistance } \\
\text { Meter }\end{array}$ & Keithley & $10^{6}$ to $10^{13} \mathrm{~W}$ & $0.125 \%$ to $1.025 \%$ \\
RES4 & Standard Resistors & $\begin{array}{l}\text { Leeds \& Northrup, } \\
\text { Julie, Guildline }\end{array}$ & $0.001 \mathrm{~W}$ to $100 \mathrm{MW}$ & $5 \mathrm{ppm}$ to $25 \mathrm{ppm}$ \\
RES5 & $\begin{array}{l}\text { Automated } \\
\text { Resistance System }\end{array}$ & $\begin{array}{l}\text { Measurements } \\
\text { International }\end{array}$ & $0.0001 \mathrm{~W}$ to $100 \mathrm{MW}$ & $0.1 \mathrm{ppm}$ to $30 \mathrm{ppm}$ (Ratio) \\
RES6 & $\begin{array}{l}\text { High Resistance } \\
\text { Measuring System }\end{array}$ & Mid-Eastern & $10^{3}$ to $10^{13} \mathrm{~W}$ & $0.13 \%$ \\
RES7 & $\begin{array}{l}\text { High Voltage } \\
\text { Resistance Standard }\end{array}$ & Spellman & $2000 \times 10^{6} \mathrm{~W}$ & $0.02 \%$ \\
RES8 & $\begin{array}{l}\text { Multifunction } \\
\text { Calibrator }\end{array}$ & Fluke & $1 \mathrm{~W}$ to $100 \mathrm{MW}$ & $15 \mathrm{ppm}$ to $100 \mathrm{ppm}$ \\
RES9 & High Precision DMM & Hewlett-Packard & $10 \mathrm{~W}$ to $100 \mathrm{MW}$ & $25 \mathrm{ppm}$ to $500 \mathrm{ppm}$ \\
\hline
\end{tabular}




\section{AC Electrical Measurement}

\section{AC Voltage}

AC voltage sources are calibrated using an Alternating Voltage Measurement Standard, which is calibrated by a DC voltage standard and standard thermal voltage converters certified for AC-DC difference by the Primary Standards Laboratory.

Test thermal voltage converter devices can be calibrated for AC-DC difference by direct comparison of their response to the response of the standard thermal voltage converter devices.

\section{AC Current}

AC current sources are calibrated using known DC current and standard current shunts, which are certified by the Primary Standards Laboratory. Current levels lower than $10 \mathrm{~mA}$ are calibrated using standard $\mathrm{AC}$ resistors. The shunts are terminated with a standard thermal voltage converter certified for AC-DC difference by the Primary Standards Laboratory. The voltage across the $\mathrm{AC}$ resistor, which is directly proportional to the current through the resistor, is measured with an $A C$ voltmeter.

\section{AC Ratio}

Decade voltage ratio transformers are calibrated by connecting a standard ratio transformer, certified by the Primary Standards Laboratory, and a test transformer to the same input signal and comparing their output signals.

\section{Capacitance and Inductance}

Calibration of capacitors and inductors is made by direct comparison of the unknown to a standard capacitor or standard inductor calibrated by the Primary Standards Laboratory. Depending on accuracy and frequency, the comparison is made on a transformer ratio arm bridge (for capacitance only) or on one of three different LCR meters.

The measurement uncertainties vary with value and frequency. Capacitance uncertainties range upward from $\pm 0.02 \%$. Inductance uncertainties range upward from $\pm 0.03 \%$. 


\section{Frequency and Time}

The GPS receiver was calibrated by the Primary Standards Laboratory and tested against their primary frequency standard using NIST's Frequency Measurement and Analysis System. The frequency standards are used to calibrate counters, sources, and time interval. A digital clock is synchronized with the time information transmitted by the WWVB signal at NIST.

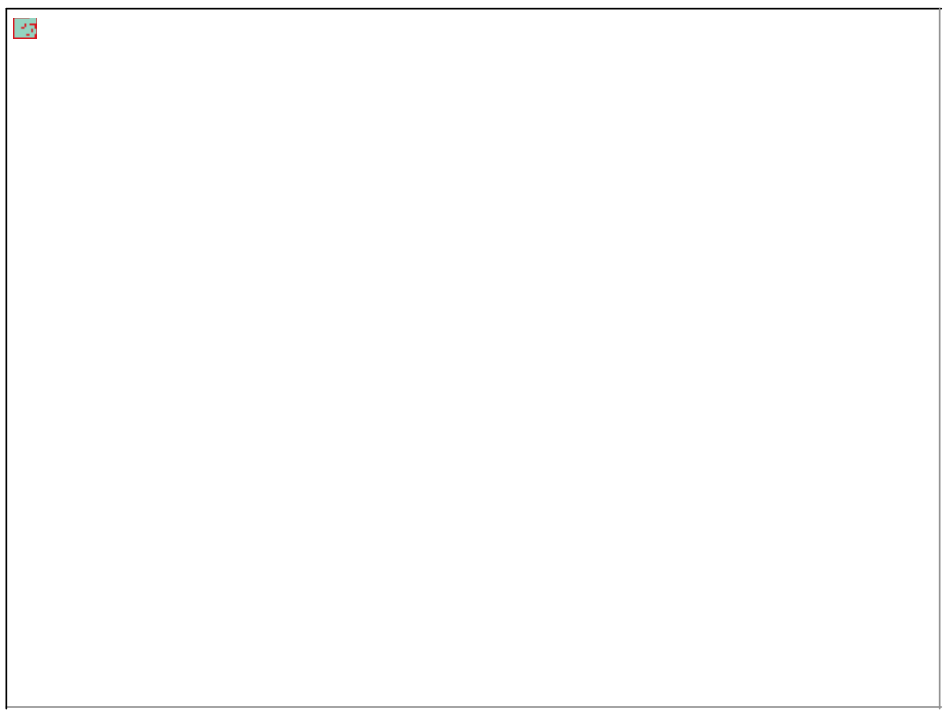

Computer-Controlled Counter Calibration 
AC Measurement Capability

\begin{tabular}{|c|c|c|c|}
\hline Type & Range & Frequency & Measuring Uncertainty (?) ( $k=2)$ \\
\hline AC Voltage * & $\begin{array}{l}2.2 \text { to } 70 \mathrm{mV} \\
2.2 \text { to } 70 \mathrm{mV} \\
70 \text { to } 700 \mathrm{mV} \\
70 \text { to } 700 \mathrm{mV} \\
700 \mathrm{mV} \text { to } 70 \mathrm{~V} \\
700 \mathrm{mV} \text { to } 70 \mathrm{~V} \\
70 \mathrm{~V} \text { to } 220 \mathrm{~V} \\
220 \mathrm{~V} \text { to } 1000 \mathrm{~V} \\
1 \text { to } 30 \mathrm{kV}\end{array}$ & $\begin{array}{l}10 \mathrm{~Hz} \text { to } 100 \mathrm{kHz} \\
100 \mathrm{kHz} \text { to } 1 \mathrm{MHz} \\
10 \mathrm{~Hz} \text { to } 100 \mathrm{kHz} \\
100 \mathrm{kHz} \text { to } 1 \mathrm{MHz} \\
10 \mathrm{~Hz} \text { to } 300 \mathrm{kHz} \\
300 \mathrm{kHz} \text { to } 1 \mathrm{MHz} \\
10 \mathrm{~Hz} \text { to } 500 \mathrm{kHz} \\
10 \mathrm{~Hz} \text { to } 100 \mathrm{kHz} \\
60 \mathrm{~Hz}\end{array}$ & $\begin{array}{l}<0.12 \%+2.5 \mathrm{mV} \\
<0.35 \%+8 \mathrm{mV} \\
<0.03 \%+2.5 \mathrm{mV} \\
<0.11 \%+8 \mathrm{mV} \\
<200 \mathrm{ppm} \\
<1200 \mathrm{ppm} \\
<500 \mathrm{ppm} \\
<800 \mathrm{ppm} \\
0.066 \%\end{array}$ \\
\hline AC Current & $10 \mathrm{~mA}$ to $20 \mathrm{~A}$ & $10 \mathrm{~Hz}$ to $50 \mathrm{kHz}$ & 0.05 to $0.07 \%$ \\
\hline Capacitance & $\begin{array}{l}0.001 \mathrm{pF} \text { to } 1 \mathrm{mF} \\
1 \text { to } 10 \mathrm{mF} \\
10 \text { to } 100 \mathrm{mF} \\
1.0 \text { to } 1000 \mathrm{pF}\end{array}$ & $\begin{array}{l}1 \mathrm{kHz} \\
1 \mathrm{kHz} \\
1 \mathrm{kHz} \\
1 \mathrm{MHz}\end{array}$ & $\begin{array}{l}(0.01 \%+0.00005 \mathrm{pF}) \\
0.02 \% \\
0.5 \% \\
0.1 \text { to } 0.2 \%\end{array}$ \\
\hline Inductance ** & $\begin{array}{l}0.05 \text { to } 2 \mathrm{mH} \\
2 \text { to } 100 \mathrm{mH} \\
100 \mathrm{mH} \text { to } 10 \mathrm{H}\end{array}$ & $\begin{array}{l}10 \mathrm{kHz} \text { to } 1 \mathrm{MHz} \\
10 \mathrm{kHz} \text { to } \mathrm{MHz} \\
1 \mathrm{kHz}\end{array}$ & $\begin{array}{l}0.7 \% \text { to } 12 \% \\
0.7 \% \text { to } 3 \% \\
0.04 \% \text { to } 0.4 \%\end{array}$ \\
\hline AC Resistance *** & $\begin{array}{l}1 \text { to } 20 \mathrm{kO} \\
0.1 \text { to } 100 \mathrm{kO}\end{array}$ & $\begin{array}{l}50 \mathrm{kHz} \\
\mathrm{DC} \text { to } 1 \mathrm{MHz}\end{array}$ & $\begin{array}{l}0.05 \% \\
0.07 \%\end{array}$ \\
\hline Frequency & $1 \mathrm{~Hz}$ to $18 \mathrm{GHz}$ & & 1 part in $10^{9}$ \\
\hline Time of Day & & & $0.5 \mathrm{~ms}$ \\
\hline
\end{tabular}

* Accuracy depending on range and frequency

** Accuracy depending on inductance and frequency

${ }^{* * *}$ Accuracy depending on resistance and frequency 


\section{AC Current, Voltage, and Ratio Traceability}

\section{AC Current, Voltage, and Ratio Standards}

\begin{tabular}{|c|c|c|c|c|}
\hline Code & Description & Manufacturer & Range & Uncertainty (?) (k=2) \\
\hline ACV1 & $\begin{array}{l}\text { Thermal } \\
\text { Converters }\end{array}$ & $\begin{array}{l}\text { Holt } \\
\text { Ballantine }\end{array}$ & $\begin{array}{l}0.5 \mathrm{~V} \text { to } 1000 \mathrm{~V}(10 \mathrm{~Hz} \text { to } 1 \mathrm{MHz}) \\
1 \mathrm{~V}(10 \mathrm{~Hz} \text { to } 100 \mathrm{MHz})\end{array}$ & $\begin{array}{l}25 \mathrm{ppm} \text { to } 110 \mathrm{ppm} \\
0.02 \text { to } 1.2 \%\end{array}$ \\
\hline ACV2 & $\begin{array}{l}\text { High Voltage } \\
\text { Divider }\end{array}$ & Julie & 20 to $100 \mathrm{kV}$ & $0.066 \%$ \\
\hline ACV3 & $\begin{array}{l}\text { Inductive } \\
\text { Ratio Divider }\end{array}$ & ESI & $\begin{array}{l}\text { Ratio only, } 0.1 \mathrm{ppm} \text { resolution } \\
(50 \mathrm{~Hz} \text { to } 10 \mathrm{kHz})\end{array}$ & 1 to $150 \mathrm{ppm}$ \\
\hline ACV4 & $\begin{array}{l}\text { AC-DC } \\
\text { Transfer } \\
\text { Standard }\end{array}$ & Fluke $5790 \mathrm{~A}$ & $\begin{array}{l}2.2 \text { to } 70 \mathrm{mV}(10 \mathrm{~Hz} \text { to } 100 \mathrm{kHz}) \\
2.2 \text { to } 70 \mathrm{mV}(100 \mathrm{kHz} \text { to } 1 \mathrm{MHz}) \\
70 \text { to } 700 \mathrm{mV}(10 \mathrm{~Hz} \text { to } 100 \mathrm{kHz}) \\
70 \text { to } 700 \mathrm{mV}(100 \mathrm{kHz} \text { to } 1 \mathrm{MHz}) \\
700 \mathrm{mV} \text { to } 70 \mathrm{~V}(10 \mathrm{~Hz} \text { to } 300 \mathrm{kHz}) \\
700 \mathrm{mV} \text { to } 70 \mathrm{~V}(300 \mathrm{kHz} \text { to } 1 \mathrm{MHz}) \\
70 \mathrm{~V} \text { to } 220 \mathrm{~V}(10 \mathrm{~Hz} \text { to } 500 \mathrm{kHz}) \\
220 \mathrm{~V} \text { to } 1000 \mathrm{~V}(10 \mathrm{~Hz} \text { to } 100 \mathrm{kHz}) \\
1 \text { to } 30 \mathrm{kV}(60 \mathrm{~Hz})\end{array}$ & $\begin{array}{l}<0.12 \%+2.5 \mathrm{mV} \\
<0.35 \%+8 \mathrm{mV} \\
<0.03 \%+2.5 \mathrm{mV} \\
<0.11 \%+8 \mathrm{mV} \\
<200 \mathrm{ppm} \\
<1200 \mathrm{ppm} \\
<500 \mathrm{ppm} \\
<800 \mathrm{ppm} \\
0.066 \%\end{array}$ \\
\hline ACV5 & Shunts & Holt & $10 \mathrm{~mA}$ to $20 \mathrm{~A}(10 \mathrm{~Hz}$ to $50 \mathrm{kHz})$ & 0.05 to $0.07 \%$ \\
\hline ACV6 & $\begin{array}{l}\text { Digital } \\
\text { Multimeter }\end{array}$ & $\begin{array}{l}\text { Hewlett } \\
\text { Packard }\end{array}$ & $\begin{array}{l}100 \mathrm{mV} \text { range } \\
1 \text { to } 100 \mathrm{~V} \text { ranges } \\
1000 \mathrm{~V} \text { range }\end{array}$ & $\begin{array}{l}15 \mathrm{ppm}+10 \mathrm{ppm} \text { of range } \\
10 \mathrm{ppm}+1 \mathrm{ppm} \text { of range } \\
20 \mathrm{ppm}+1 \mathrm{ppm} \text { of range }\end{array}$ \\
\hline ACV7 & $\begin{array}{l}\text { Calibrated } \\
\text { DC Voltage } \\
\text { Source }\end{array}$ & Fluke & 10 to $1000 \mathrm{~V}$ three ranges & $<15$ ppm \\
\hline \multirow[t]{10}{*}{ ACV8 } & AC Calibrator & Fluke & $1 \mathrm{mV}$ to $100 \mathrm{mV}(10 \mathrm{~Hz}$ to $30 \mathrm{kHz})$ & $\begin{array}{l}0.02 \% \text { of setting } \\
+0.005 \% \mathrm{FS}+10 \mathrm{mV}\end{array}$ \\
\hline & & & $1 \mathrm{~V}$ to $100 \mathrm{~V}(10 \mathrm{~Hz}$ to $50 \mathrm{kHz})$ & $\begin{array}{l}0.02 \% \text { of setting } \\
+0.005 \% \mathrm{FS}+10 \mathrm{mV}\end{array}$ \\
\hline & & & $1 \mathrm{mV}$ to $100 \mathrm{mV}(30 \mathrm{kHz}$ to $100 \mathrm{kHz})$ & $\begin{array}{l}0.06 \% \text { of setting } \\
+0.006 \% \mathrm{FS}+10 \mathrm{mV}\end{array}$ \\
\hline & & & $1 \mathrm{~V}$ to $10 \mathrm{~V}(50 \mathrm{kHz}$ to $100 \mathrm{kHz})$ & $\begin{array}{l}0.06 \% \text { of setting } \\
+0.006 \% \mathrm{FS}+10 \mathrm{mV}\end{array}$ \\
\hline & & & $1000 \mathrm{~V}$ range $(50 \mathrm{~Hz}$ to $1 \mathrm{kHz})$ & $\begin{array}{l}0.06 \% \text { of setting } \\
+0.006 \% \mathrm{FS}+10 \mathrm{mV}\end{array}$ \\
\hline & & & $1 \mathrm{mV}$ to $100 \mathrm{mV}(100 \mathrm{kHz}$ to $1 \mathrm{MHz})$ & $0.6 \%$ of setting $+0.1 \% \mathrm{FS}$ \\
\hline & & & $1 \mathrm{~V}$ to $10 \mathrm{~V}(100 \mathrm{kHz}$ to $1 \mathrm{MHz})$ & $0.4 \%$ of setting $+0.1 \% \mathrm{FS}$ \\
\hline & & & $100 \mathrm{~V}$ range $(50 \mathrm{kHz}$ to $100 \mathrm{kHz})$ & $0.1 \%$ of setting \\
\hline & & & $\begin{array}{l}\text { Wideband output } \\
\qquad \begin{aligned} & 10 \text { to } 30 \mathrm{~Hz} \\
&>30 \mathrm{~Hz} \text { to } 1 \mathrm{MHz} \\
&>1 \mathrm{MHz} \text { to } 20 \mathrm{MHz} \\
&>20 \mathrm{MHz} \text { to } 30 \mathrm{MHz}\end{aligned}\end{array}$ & $\begin{array}{l}0.3 \% \\
0.25 \% \\
0.75 \% \\
1.0 \%\end{array}$ \\
\hline & & & to $2 \mathrm{~A}$ & $\begin{array}{l}0.07 \% \text { of setting }+0.01 \% \text { of } \\
\text { range }\end{array}$ \\
\hline
\end{tabular}




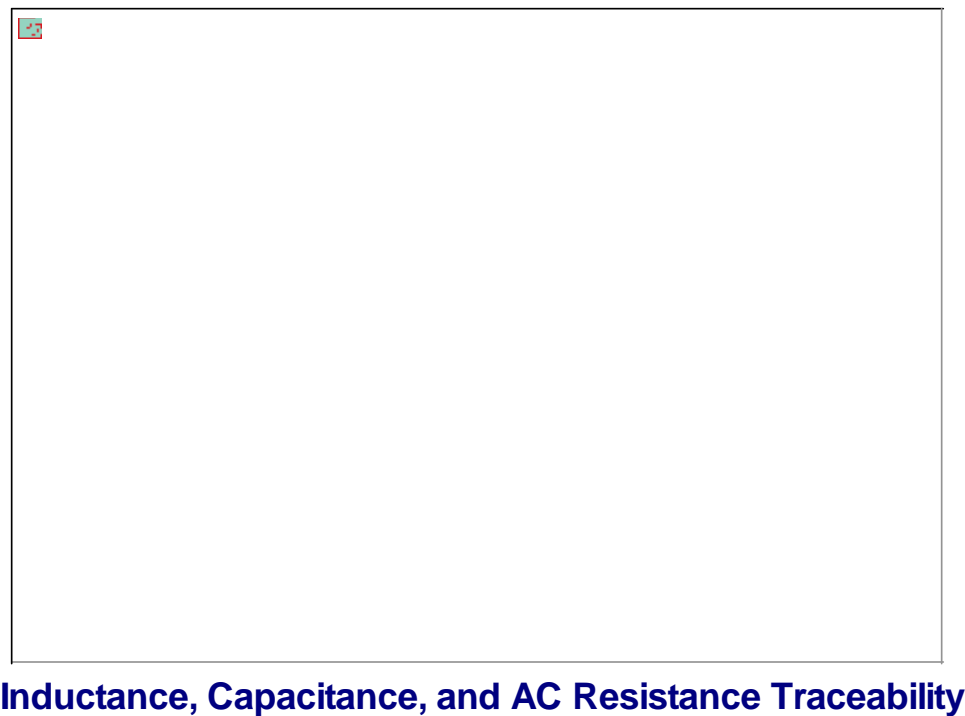




\section{Inductance, Capacitance, and AC Resistance Standards}

\begin{tabular}{|c|c|c|c|c|}
\hline Code & Description & Manufacturer & Range & Uncertainty (?) (k=2) \\
\hline ACZ1 & Standard Inductors & $\begin{array}{l}\text { General Radio, } \\
\text { FM\&T Metrology, } \\
\text { Hewlett-Packard, } \\
\text { Boonton }\end{array}$ & $\begin{array}{l}50 \mathrm{mH} \text { to } 10 \mathrm{H} \\
50 \mathrm{nH} \text { to } 100 \mathrm{mH}\end{array}$ & $\begin{array}{l}0.03 \text { to } 0.3 \% \text { * } \\
0.3 \text { to } 10 \% \text { * }\end{array}$ \\
\hline ACZ2 & Standard Capacitors & General Radio & $1000 \mathrm{pF}$, fixed & $0.003 \%$ at $1 \mathrm{kHz}$ \\
\hline ACZ3 & Standard Resistors & $\begin{array}{l}\text { Leeds \& Northrup } \\
\text { Hewlett-Packard }\end{array}$ & $\begin{array}{l}1 \text { to } 20 \mathrm{~kW} \\
0.1 \text { to } 100 \mathrm{~kW}\end{array}$ & $\begin{array}{l}0.015 \% \\
0.05 \%\end{array}$ \\
\hline ACZ4 & LCR Meter & Hewlett-Packard & $\begin{array}{l}100 \mathrm{mH} \text { to } 5 \mathrm{H} \\
0.05 \mathrm{mH} \text { to } 10 \mathrm{mH}\end{array}$ & $\begin{array}{l}0.15 \text { to } 0.3 \% \\
\text { (direct measurement) } \\
0.1 \text { to } 10 \% \text { (comparison to } \\
\text { standard inductors) }\end{array}$ \\
\hline ACZ6 & Capacitance Bridge & $\begin{array}{l}\text { General Radio } \\
\text { Hewlett-Packard }\end{array}$ & $\begin{array}{l}0.001 \mathrm{pF} \text { to } 1 \mathrm{mF} \\
1 \mathrm{mF} \text { to } 10 \mathrm{mF} \\
0.1 \text { to } 1000 \mathrm{pF}\end{array}$ & $\begin{array}{l}0.01 \%+0.00005 \mathrm{pF} \\
0.02 \%(\text { at } 1 \mathrm{kHz}) \\
0.1 \% \text { at } 1 \mathrm{kHz} \\
0.2 \% \text { at } 1 \mathrm{MHz}\end{array}$ \\
\hline ACZ7 & $\begin{array}{l}\text { Reference } \\
\text { Capacitors }\end{array}$ & $\begin{array}{l}\text { Boonton Electric } \\
\text { General Radio } \\
\text { FM\&T Metrology }\end{array}$ & $\begin{array}{l}1 \text { to } 1000 \mathrm{pF} \\
0.1 \text { to } 1000 \mathrm{pF} \\
0.001 \text { to } 1 \mathrm{mF} \\
1 \text { to } 10 \mathrm{mF} \text { in } \\
1 \mathrm{mF} \text { increments } \\
10 \text { to } 100 \mathrm{mF} \text { in } \\
10 \mathrm{mF} \text { increments }\end{array}$ & $\begin{array}{l}0.02 \% \text { to } 0.11 \% \text { ** } \\
0.1 \text { to } 0.15 \%{ }^{* *} \\
0.02 \% \text { at } 1 \mathrm{kHz} \\
0.1 \% \text { at } 1 \mathrm{kHz} \\
0.1 \% \text { at } 1 \mathrm{kHz}\end{array}$ \\
\hline
\end{tabular}

\footnotetext{
* Uncertainty depending on inductance value and frequency

** Uncertainty depending on capacitance value and frequency

*** Uncertainty depending on resistance value and frequency
} 


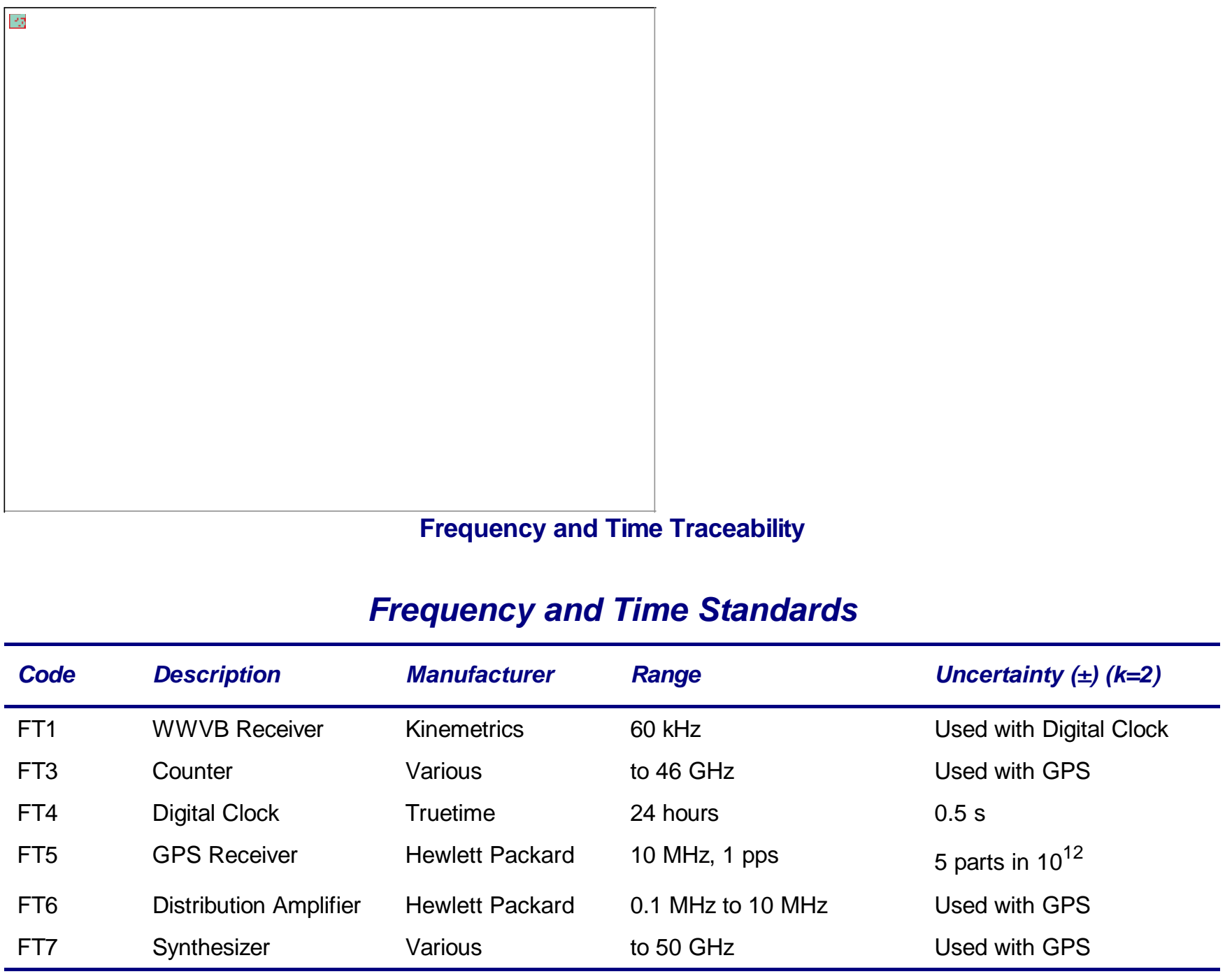




\section{RF/MICROWAVE MEASUREMENTS}

\section{Air Lines}

Air line impedance standards are calibrated using dimensional measurement techniques. The inner and outer conductors' diameters are measured using air gages, and the lengths are measured using a length measurement system by comparison to gage blocks of similar lengths. The dimensional measurements are used to calculate the impedance and electrical length.

\section{Attenuators and Terminations}

Standard attenuators and terminations are calibrated by NIST and certified for calibrating Attenuation and Network Analyzer systems and to transfer their values by comparison to other attenuators and terminations.

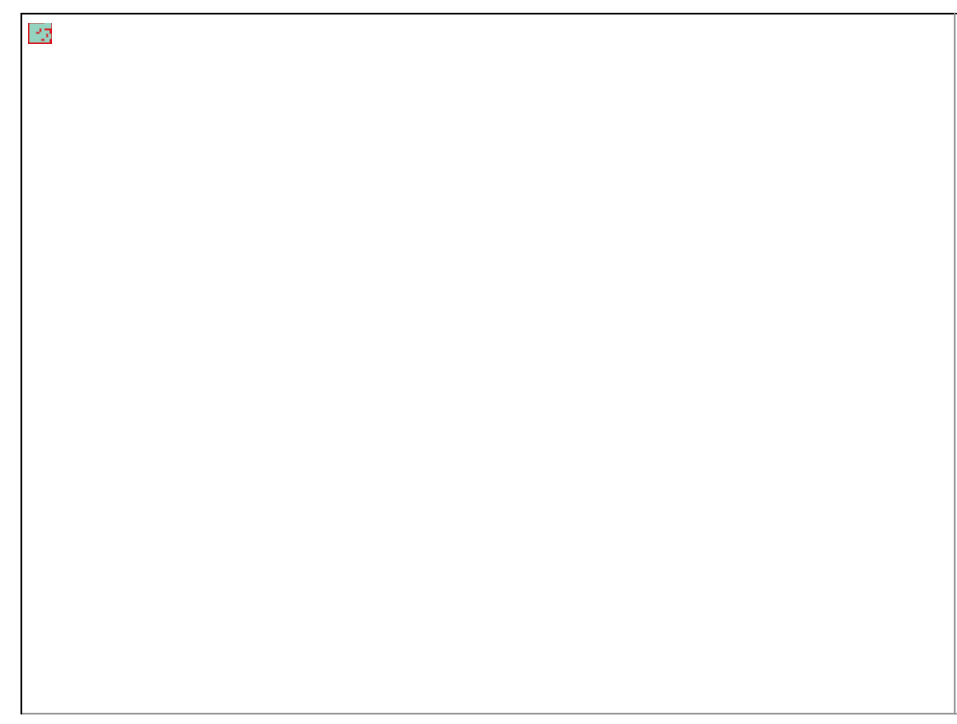

Attenuator Calibration Using an Automatic Network Analyzer 


\section{Network Analyzers and Attenuation Systems}

Network analyzers and attenuation systems are calibrated over their operating range by air lines and NIST-calibrated terminations and attenuators. They are used to calibrate single and multi-port devices for s-parameter measurements.

\section{Noise Source}

Standard noise sources are calibrated for excess noise ratio (ENR) across a frequency range at the Primary Standards Laboratory (PSL). They are used to transfer the ENR values by comparison to other noise sources.

\section{Thermistor Mounts}

Standard thermistor mounts are calibrated by PSL and certified for calibrating a Power Meter/Sensor Calibration system and transferring the calibration factor values by comparison to other thermistor mounts. 


\section{Probe Station}

The probe station is used to measure chip devices and wafer components. NIST reference materials are available for comparisons. The probes are $100 \mu \mathrm{m}$ to $3000 \mu \mathrm{m}$ widths, GS, SG, and Ground Signal Ground with cal substrates.

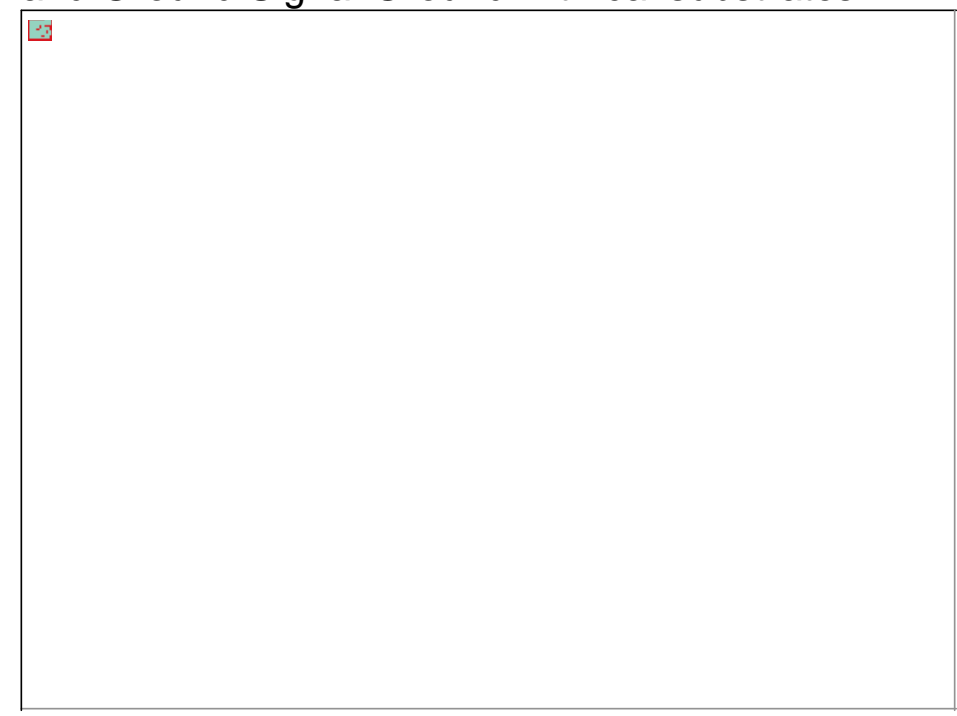

Probe Station 


\section{Power System}

The power system is calibrated by transferring the calibration factors from PSL calibrated thermistor mounts to the systems reference sensor. The power system is used to calibrate power meters, sensors, and thermistor mounts.

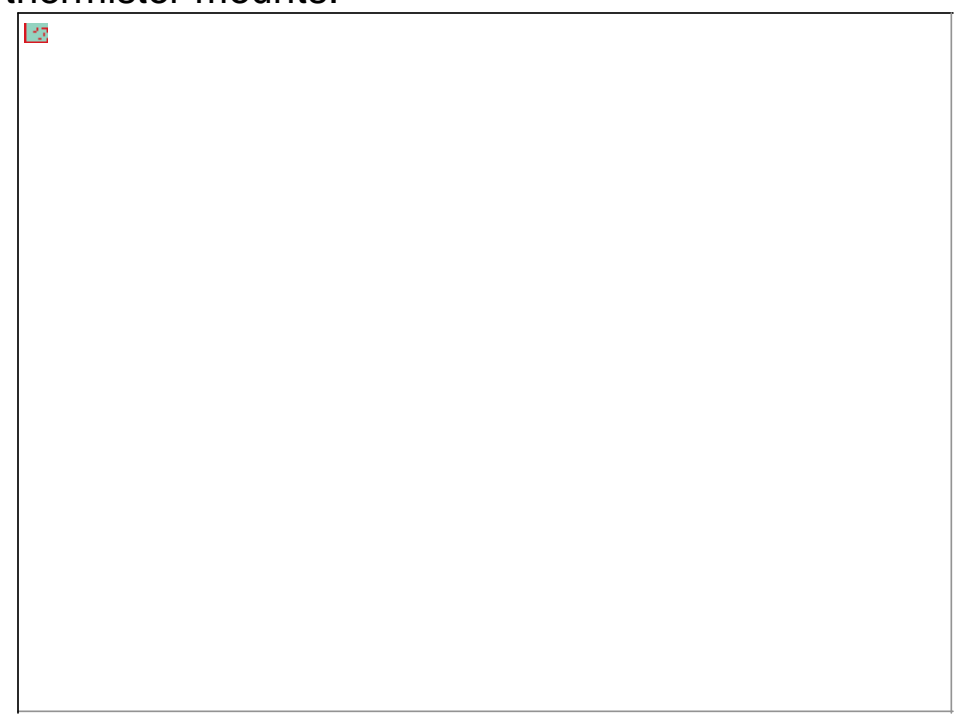

Power Meter Calibration 


\section{Electrical Radio Frequency/Microwave Measurement Capability}

\begin{tabular}{|c|c|c|c|}
\hline Type & Range & Frequency & $\begin{array}{l}\text { Measuring } \\
\text { Uncertainty ( }( \pm)(k=2)\end{array}$ \\
\hline Air Lines (Air-Dielectric) & $\begin{array}{l}\text { Impedance } \\
\text { Electrical Length ( } 3 \text { to } 30 \mathrm{~cm})\end{array}$ & $\begin{array}{l}50 \mathrm{MHz} \text { to } 26.5 \mathrm{GHz} \\
50 \mathrm{MHz} \text { to } 26.5 \mathrm{GHz}\end{array}$ & $\begin{array}{l}0.028 \mathrm{~W} \text { to } 0.20 \mathrm{~W} \\
0.0019 \mathrm{~cm} \text { to } 0.03 \mathrm{~cm}\end{array}$ \\
\hline \multicolumn{4}{|l|}{ Scattering Parameters ${ }^{1}$} \\
\hline \multirow[t]{2}{*}{$|\mathrm{G}|$} & $\left|S_{i i}\right|, 0$ to 1 & $300 \mathrm{kHz}$ to $26.5 \mathrm{GHz}$ & 0.001 to 0.035 \\
\hline & $\left|S_{\mathrm{ii}}\right|, 0$ to 1 & $>26.5 \mathrm{GHz}$ to $50 \mathrm{GHz}$ & Capability \\
\hline \multirow[t]{2}{*}{ G Phase } & $\operatorname{Arg}\left(S_{i i}\right),-180^{\circ}$ to $180^{\circ}$ & $300 \mathrm{kHz}$ to $26.5 \mathrm{GHz}$ & $0.35^{\circ}$ to $180^{\circ}$ \\
\hline & $\operatorname{Arg}\left(S_{i i}\right),-180^{\circ}$ to $180^{\circ}$ & $>26.5 \mathrm{GHz}$ to $50 \mathrm{GHz}$ & Capability \\
\hline \multirow[t]{2}{*}{ Attenuation } & $\left|\mathrm{S}_{\mathrm{ij}}\right|, 0 \mathrm{~dB}$ to $70 \mathrm{~dB}$ & $300 \mathrm{kHz}$ to $26.5 \mathrm{GHz}$ & $0.01 \mathrm{~dB}$ to $1.1 \mathrm{~dB}$ \\
\hline & $\left|\mathrm{S}_{\mathrm{ij}}\right|, 0 \mathrm{~dB}$ to $70 \mathrm{~dB}$ & $>26.5 \mathrm{GHz}$ to $50 \mathrm{GHz}$ & Capability \\
\hline Transmission Phase & $\operatorname{Arg}\left(S_{i j}\right), \quad 0 d B$ to $70 \mathrm{~dB}$ & $300 \mathrm{kHz}$ to $50 \mathrm{GHz}$ & Capability \\
\hline Thermistor Mounts ${ }^{1}$ & Calibration Factor (0.9 to 1.0$)$ & $1 \mathrm{MHz}$ to $18 \mathrm{GHz}$ & $0.5 \%$ to $5 \%$ \\
\hline $\begin{array}{l}\text { CW Power Meter } \\
\text { Systems }{ }^{1}\end{array}$ & $\begin{array}{l}10 \mu \mathrm{W} \text { to } 100 \mathrm{~mW} \\
10 \mu \mathrm{W} \text { to } 100 \mathrm{~mW} \\
1 \mathrm{nW} \text { to } 10 \mu \mathrm{W} \\
100 \mathrm{~mW} \text { to } 5 \mathrm{~W}\end{array}$ & $\begin{array}{l}100 \mathrm{kHz} \text { to } 4.2 \mathrm{GHz} \\
>4.2 \mathrm{GHz} \text { to } 18 \mathrm{GHz} \\
10 \mathrm{MHz} \text { to } 18 \mathrm{GHz} \\
10 \mathrm{MHz} \text { to } 1.0 \mathrm{GHz}\end{array}$ & $\begin{array}{l}2.4 \% \text { to } 4.2 \% \\
3.0 \% \text { to } 10 \% \\
2.5 \% \text { to } 10 \% \\
5 \% \text { + Additional Unc. }\end{array}$ \\
\hline $\begin{array}{l}\text { Peak Power Meter } \\
\text { Systems }{ }^{1}\end{array}$ & $10 \mu \mathrm{W}$ to $100 \mathrm{~mW}$ & $1 \mathrm{GHz}$ to $2 \mathrm{GHz}$ & $5 \%$ \\
\hline Group Delay $^{1}$ & $1 \mathrm{~ns}$ to $1200 \mathrm{~ns}$ & $50 \mathrm{MHz}$ to $2.0 \mathrm{GHz}$ & $0.005 \mathrm{~ns}$ to $0.5 \mathrm{~ns}$ \\
\hline Noise Sources ${ }^{1}$ & $\mathrm{ENR} \sim 15 \mathrm{~dB}$ & $60 \mathrm{MHz}$ to $3.55 \mathrm{GHz}$ & $0.1 \mathrm{~dB}$ to 0.35 \\
\hline $\begin{array}{l}\text { Chip Devices/Wafer } \\
\text { Components }\end{array}$ & Various Measurements & dc to $50 \mathrm{GHz}$ & Capability \\
\hline
\end{tabular}

${ }^{1}$ Referenced to $50 \mathrm{~W}+\mathrm{j} 0 \mathrm{~W}$. 


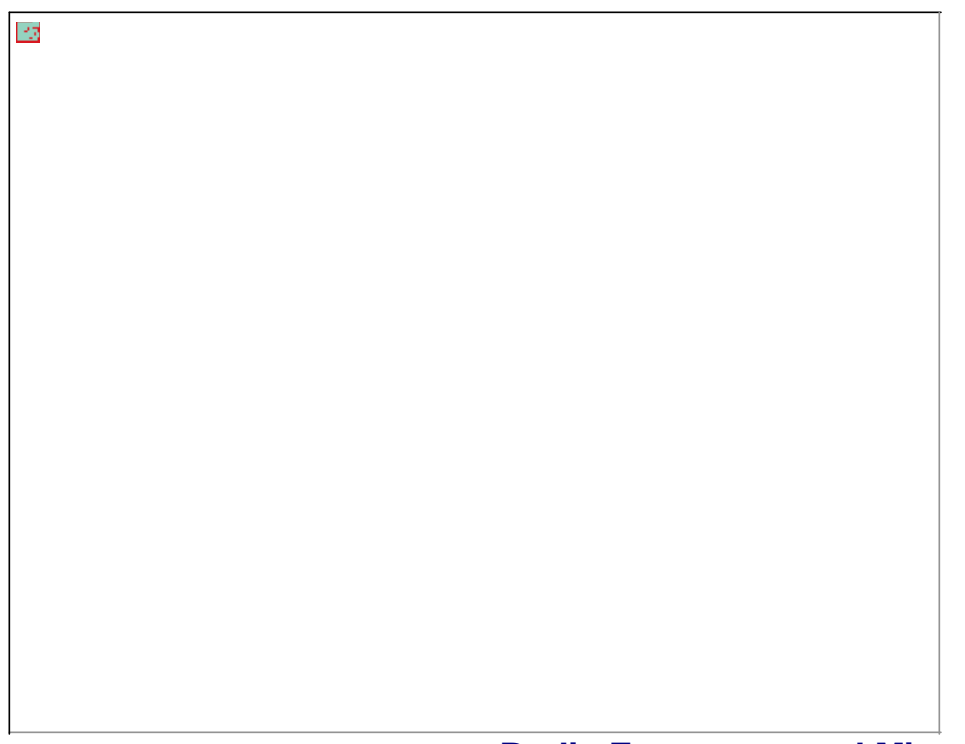

Radio Frequency and Microwave Traceability 


\section{Radio Frequency and Microwave Standards}

\begin{tabular}{|c|c|c|c|c|}
\hline Code & Description & Manufacturer & Range & Uncertainty $(k=2)$ \\
\hline \multirow[t]{2}{*}{ MW1 } & Air Lines & General Radio & $\begin{array}{l}3.5 \mathrm{~mm}, 7 \mathrm{~mm}, 14 \mathrm{~mm} \text {, } \\
\text { and } \mathrm{N}\end{array}$ & $|Z| \pm 0.028 W$ to $0.20 W$ \\
\hline & & Maury Microwave & $50 \mathrm{MHz}$ to $26.5 \mathrm{GHz}$ & $\begin{array}{l}\text { E.L. } \pm 0.0019 \mathrm{~cm} \text { to } 0.03 \\
\mathrm{~cm}\end{array}$ \\
\hline MW2 & Attenuators & Hewlett Packard & $\begin{array}{l}10 \mathrm{~dB}, 300 \mathrm{kHz} \text { to } \\
26.5 \mathrm{GHz}\end{array}$ & $\pm 0.008 \mathrm{~dB}$ to $0.042 \mathrm{~dB}$ \\
\hline MW3 & Terminations & General Radio Wiltron & $300 \mathrm{kHz}$ to $100 \mathrm{MHz}$ & $\begin{array}{l}|\mathrm{G}| \pm 0.0008 \text { to } 0.003 \\
\mathrm{f} \pm 0.2^{\circ} \text { to } 180^{\circ}\end{array}$ \\
\hline MW4 & GPS Receiver & Hewlett Packard & $10 \mathrm{MHz}$ & $\pm 0.000005 \mathrm{ppm}$ \\
\hline \multirow[t]{3}{*}{ MW5 } & $\begin{array}{l}\text { Network } \\
\text { Analyzers }\end{array}$ & Hewlett Packard & $300 \mathrm{kHz}$ to $26.5 \mathrm{GHz}$ & $|\mathrm{G}| \pm 0.001$ to 0.035 \\
\hline & & & $\begin{array}{l}|\mathrm{G}|, 0 \text { to } 1 \\
\text { f, }-180^{\circ} \text { to } 180^{\circ}\end{array}$ & $\mathrm{f} \pm 0.35^{\circ}$ to $180^{\circ}$ \\
\hline & & & Attenuation: 0 to $70 \mathrm{~dB}$ & \\
\hline MW6 & Noise Source & Hewlett Packard & $60 \mathrm{MHz}$ to $3.55 \mathrm{GHz}$ & \pm 0.1 to $0.35 \mathrm{~dB}$ \\
\hline MW7 & $\begin{array}{l}\text { Thermistor } \\
\text { Mounts }\end{array}$ & Hewlett Packard & $1 \mathrm{MHz}$ to $18 \mathrm{GHz}$ & $\pm 0.3 \%$ to $1.5 \%$ \\
\hline MW8 & Probe Station & & $\mathrm{dc}$ to $50 \mathrm{GHz}$ & $\begin{array}{l}\text { Used with other } \\
\text { calibrated measuring } \\
\text { standards. }\end{array}$ \\
\hline MW9 & Power System & FM\&T Metrology & $1 \mathrm{MHz}$ to $18 \mathrm{GHz}$ & $\pm 1.0 \%$ to $4 \%$ \\
\hline
\end{tabular}




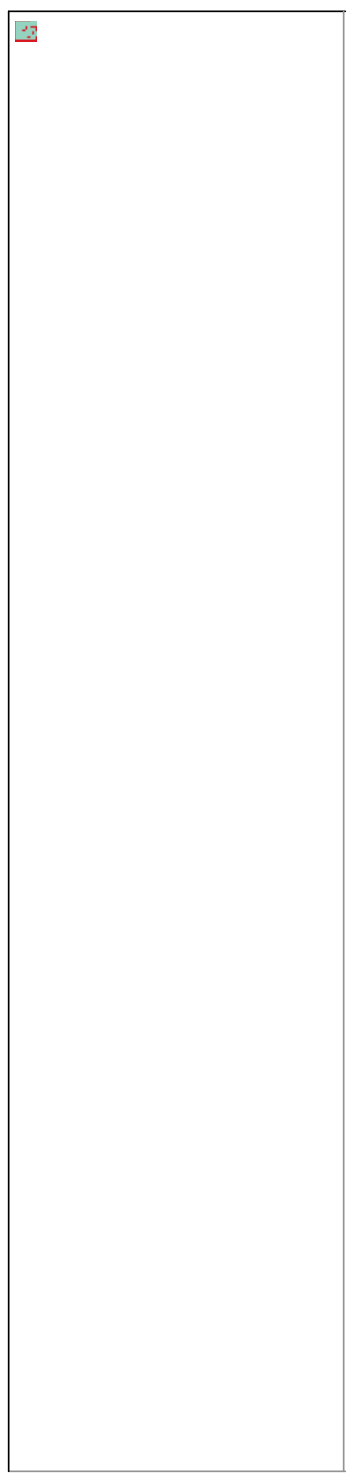

\section{OPTICAL AND RADIATION}

\section{Optical Radiometric Measurement}

Radiometry is the measurement of radiation in the optical spectrum, which includes ultraviolet, visible, and infrared light. The main radiometric reference standards at FM\&T are heat-flow calorimeters and wavelength standards, which include Helium-Neon (HeNe) lasers and Mercury spectral lamps. The Primary Standards Laboratory calibrates the heat flow calorimeters. The HeNe laser wavelength standard is calibrated by NIST because of its low uncertainty. The mercury spectral lamps do not require calibration because of their physical characteristics. Measurements performed include noncoherent measurement in the ultraviolet and visible regions of the optical spectrum and coherent measurements, which consist of HeNe, $\mathrm{Nd}: \mathrm{YAG}$, and $\mathrm{CO}_{2}$ 
lasers. Power levels of these measurements range from fractions of a microwatt to levels in excess of 1000 watts over wavelengths of $365 \mathrm{~nm}$ to $10.6 \mathrm{~mm}$. Most of the radiometric calibration activity at FM\&T is calibrating Nd:YAG and $\mathrm{CO}_{2}$ laser power sensors and meters in $\mathrm{CW}$ mode.

\section{Optical Photometric Measurement}

Photometry is the measurement of visible light intensity and energy as it affects the human eye. The main photometric reference standards at FM\&T are standard photometers, calibrated by NIST. Standard photometers output current and are used with a digital picoammeter to measure illuminance in units of footcandles or lux. When used in conjunction with an optical bench, luminous intensity, in units of candela, can be measured.

\section{Radiation Measurement}

Radiation measurements are made using standards of alpha-particle emission rate from plutonium 239 and lead-probe neutron detectors. Alpha sources and lead probes are calibrated by the PSL. Accuracy of these standards ranges from $\pm 3 \%$ to $\pm 10 \%$.

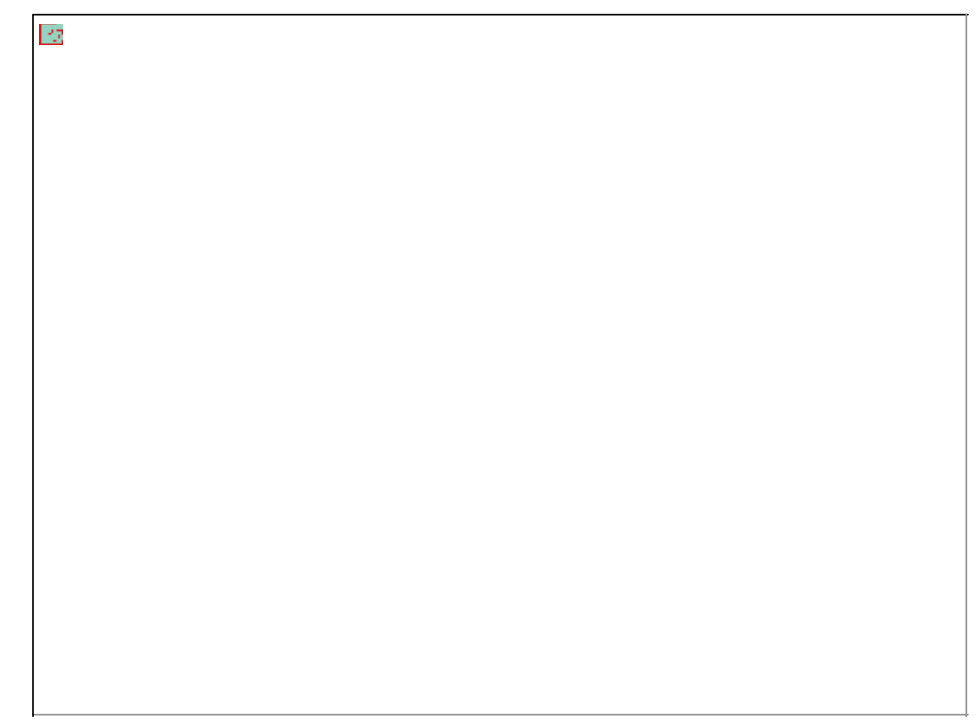

Photodiode Detector Calibration

Optical Radiometric Measurement Capability

\begin{tabular}{|c|c|c|}
\hline Type & Range & Measuring Uncertainty (?) (k=2) \\
\hline Optical Transmittance & $1=235$ to $1100 \mathrm{~nm}$ & $1.5 \%$ \\
\hline Optical Spectral Response & $\begin{array}{l}235 \text { to } 400 \mathrm{~nm} \\
400 \text { to } 900 \mathrm{~nm}\end{array}$ & $\begin{array}{l}5 \% \\
1.5 \%\end{array}$ \\
\hline Laser Average Power & $\begin{aligned} 1= & 488 \mathrm{~nm} \text { to } 1.064 \mathrm{~mm} \\
& 1 \mathrm{~mW} \text { to } 1 \mathrm{~mW} \\
& 1 \mathrm{~mW} \text { to } 10 \mathrm{~W} \\
1= & 10.6 \mathrm{~mm} \\
& 1 \mathrm{~mW} \text { to } 10 \mathrm{~W} \\
& 10 \text { to } 1000 \mathrm{~W}\end{aligned}$ & $\begin{array}{l}1.5 \% \\
1.0 \% \\
3 \% \\
6 \%\end{array}$ \\
\hline LED Power & $\begin{aligned} \mathrm{l}= & 570 \text { to } 910 \mathrm{~nm} \\
& 10 \mathrm{~mW} \text { to } 10 \mathrm{~mW}(\mathrm{CW})\end{aligned}$ & $5 \%$ \\
\hline Ultraviolet Irradiance & $\begin{aligned} \mathrm{l}= & 254 \mathrm{~nm} \text { and } 365 \mathrm{~nm} \\
& 0.1 \text { to } 10 \mathrm{~mW} / \mathrm{cm}^{2}\end{aligned}$ & $3 \%$ \\
\hline
\end{tabular}




\begin{tabular}{|c|c|c|c|c|}
\hline & 国 & & & \\
\hline & Description & Manutacturer & Range & Uncertainty (?) (k=2) \\
\hline OR2 & Calorimeter & Scientech & $\begin{array}{l}1 \mathrm{~mW} \text { to } 10 \mathrm{~W} \\
365 \mathrm{~nm} \text { to } 1100 \mathrm{~nm} \\
10.6 \mathrm{~mm}\end{array}$ & $\begin{array}{l}1.0 \% \\
3 \%\end{array}$ \\
\hline OR3 & $\begin{array}{l}\text { Digital } \\
\text { Nanovoltmeter }\end{array}$ & Keithley & $2 \mathrm{mV}$ to $200 \mathrm{~V}$ & $\begin{array}{l}(0.015 \% \text { of reading }+10 \text { digits }) \text { to } \\
(0.01 \% \text { of reading }+2 \text { digits })\end{array}$ \\
\hline OR4 & $\begin{array}{l}\text { Mercury Spectral } \\
\text { Lamp }\end{array}$ & Oriel & 237.8 to $1092.2 \mathrm{~nm}$ & $0.1 \mathrm{~nm}$ \\
\hline OR5 & Monochromator & Various & 235 to $1092.2 \mathrm{~nm}$ & $1.0 \mathrm{~nm}$ \\
\hline OR6 & $\begin{array}{l}\text { Photodiode Trap } \\
\text { Detector }\end{array}$ & FM\&T & $\begin{array}{l}400 \text { to } 900 \mathrm{~nm} \\
1 \mathrm{~mW} \text { to } 2 \mathrm{~mW}\end{array}$ & $1.5 \%$ \\
\hline OR7 & HeNe Laser & Hewlett Packard & $632.991 \mathrm{~nm}$ & 0.015 ppm \\
\hline OR8 & $\begin{array}{l}\text { Photographic Step } \\
\text { Tablet }\end{array}$ & NIST & 0 to 4 density units & 0.006 density units \\
\hline
\end{tabular}




\section{Nd:YAG Laser Power Meter Calibration}

\section{Optical Photometric Measurement Capability}

\begin{tabular}{|l|l|l|}
\hline Type & Range & Measuring Uncertainty (?) (k=2) \\
\hline Illuminance & 1 to 500 foot-candle & $1.5 \%$ \\
\hline Luminous Intensity & 100 to 750 candela & $2.0 \%$ \\
\hline
\end{tabular}

\begin{tabular}{|c|c|c|c|c|}
\hline 四 & & $\begin{array}{r}\text { Op } \\
\text { Ptical Pho }\end{array}$ & $\begin{array}{l}\mid \\
\text { metric Measurem }\end{array}$ & tandards \\
\hline Code & Description & Manufacturer & Range & Uncertainty (?) (k=2) \\
\hline OP2 & $\begin{array}{l}\text { Standard } \\
\text { Photometer }\end{array}$ & Graseby & 0.1 to 2000 foot-candles & $1.5 \%$ \\
\hline OP3 & $\begin{array}{l}\text { Digital } \\
\text { Picoammeter }\end{array}$ & Keithley & $200 \mathrm{nA}$ to $20 \mathrm{~mA}$ & $\begin{array}{l}(0.4 \% \text { of reading }+4 \\
\text { digits) to }(0.1 \% \text { of } \\
\text { reading }+1 \text { digit }\end{array}$ \\
\hline OP4 & Optical Bench & Ealing & 0 to $200 \mathrm{~cm}$ & $0.1 \mathrm{~cm}$ \\
\hline
\end{tabular}

